\title{
Restructuring with What Success? A Case Study of Russian Firms
}

\author{
By: Susan J. Linz \\ Working Paper Number 324
}

July 2000 
Revised: July 2000

\title{
Restructuring with What Success? A Case Study of Russian Firms
}

\author{
Susan Linz
}

This case study of enterprise restructuring utilizes data collected from thirty-two former state-owned firms in Taganrog, Russia, in the summer and fall of 1999. These data are used to construct three composite measures of enterprise restructuring. When defined broadly to include several dimensions of the restructuring process, the "restructuring threshold" is achieved by half of the privatized firms participating in the project. The firms achieving this threshold are distributed across all industries included in the sample. Regardless of the composite measure used, more than one-third of the former state-owned firms participating in this project attained the "active" restructuring designation. The results indicate that (1) production assortment changes appear to be ongoing among those firms engaged in restructuring activities, (2) employment changes appear to involve a mixed strategy with regard to timely wage payments, workforce size, and the benefits package; and (3) outsider ownership is more prevalent among the group of firms designated as restructuring than among those firms that failed to achieve the "restructuring threshold". To put into perspective the economic and business environment in which these former state-owned firms operate, a comparison is made to a group of de novo firms that were surveyed under the auspices of the same project.

Key Words: Russia, enterprise restructuring, privatization

JEL Classification: P2, L2, L33, P42

Research for this paper was supported by a grant from the International Research \& Exchanges Board, with funds provided by the US Department of State (Title VIII Program) and the National Endowment for the Humanities. None of these organizations is responsible for the views expressed. I thank two anonymous readers for comments on an earlier draft. 


\section{Introduction}

Little debate surrounds the proposition that former state-owned firms in Russia must restructure their organization and operations in order to survive the transition from a planned economy to a market economy. Moreover, little debate surrounds the nature and scope of enterprise restructuring that must take place for firm survival to be an option. Restructuring involves changes in the quantity and assortment of production, with corresponding changes in the size and skill composition of the workforce, the quantity and quality of the physical capital stock, the organization of production, and the number and location of suppliers and buyers, for example. Few debate whether enterprise restructuring in Russia has been hampered by new financial arrangements associated with new ownership structures and reduced financial support from banking and other central or local authorities.

Given persistent adverse economic conditions throughout the 1990s, however, considerable and spirited debate among researchers and policy makers continues to surround the query: With what success are Russian firms restructuring? Throughout the 1990s, Russia experienced industrial production declines more than double that of corresponding employment reductions; investment expenditures failed to reach $25 \%$ of the pre-transition level despite the need to renovate more than $50 \%$ of the capital stock; a growing proportion of manufacturing firms each year reported zero profits (Goskomstat 1999). Aggregate data suggested that throughout the 1990s, Russian firms, if restructuring at all, were failing to restructure at a pace that would facilitate the transition to a market economy. A growing literature purports to demonstrate how Russian firms purposefully avoided changes that would have improved their overall operations. ${ }^{\mathrm{A}}$ At the same time, however, firm-level

\footnotetext{
${ }^{1}$ Ickes and Gaddy (1998 1999), Ickes and Ericson (2000); see also, Pervalov et al (1999).
} 
data collected in numerous small-scale survey projects ${ }^{\text {Q }}$ detail a wide variety of efforts by managers to change production, employment and financing in order to ensure the ongoing operation and survival of their firm. The $20^{\text {th }}$ century ended with the jury still out regarding the restructuring success experienced by Russian firms.

Why does it matter whether Russian firms are restructuring? If we take as the premise Russian firms are not restructuring - then a set of policy options designed to initiate restructuring would be appropriate to consider. If we take as the premise - Russian firms are restructuring but their efforts have been impeded or the outcomes have not been accurately recorded - then a different set of policy options would be appropriate to adopt. Thus, the greater the detail provided about the operation and performance of Russian firms, the better able policy makers will be to adopt the appropriate measures to facilitate enterprise restructuring and the overall transition process, and the more informed business leaders in the global community will be in terms of investment strategies in Russia.

This case study of enterprise restructuring utilizes data collected from thirty-two former stateowned firms in Taganrog, ${ }^{\text {B }}$ Russia, in the summer and fall of 1999. These data are used to construct three composite measures of enterprise restructuring. The results illustrate the variation in

\footnotetext{
${ }^{2}$ See, for example, Blasi et al (1997), Boycko et al (1995), Buck et al (1994), Commander and Mumssen (1998), Dolgopyatova (1995), Earle and Estrin (1997), Hendley et al (1997), Ickes et al (1995), Jones (1998), Krueger (1995), Linz (1993 1997 1998), Linz and Biddle (1998), Linz and Krueger (1996 1998), Nelson and Kuzes (1994), Standing (1996).

${ }^{3}$ Financial constraints limited the project to a single location. Previously-established connections with local officials made it possible to complete the project in Taganrog. While it is the case that Taganrog has been identified by Soviet and Russian researchers as the "average city" of Russia, the former Soviet Union (see, for example, Grushin (1980), Rimashevskaya (1992), and Chichiliymov (1999), among others), it is not the case that the thirty-two firms participating in this project were selected in such a way as to reflect the composition of former state-owned firms in all of Russia, or even Taganrog. The selection process targeted including one-third heavy industry, one third light/food industry, and one-third "other industry."
} 
restructuring activities across privatized firms, as well as identify the most commonly adopted changes. The case study also draws on a survey of 87 never state-owned (de novo) firms conducted in Taganrog at the same time. Where variables are comparable between the two groups of firms, it is possible to identify similarities and differences among the survival strategies of these firms. Detailed and comparative information on enterprise operations is invaluable in gauging the impact of economic conditions on business operations, as well as to highlight policy options that would be most effective in stimulating improved performance. Detailed and comparative information delineating enterprise operations also puts into perspective some fraction of what is required for former state-owned firms in Russia to initiate and sustain restructuring activities.

The paper is divided into five sections. The first section specifies the composite measure of enterprise restructuring. The second presents the methodology employed to evaluate the relative success of Russian firms in this regard. The third section describes the firms participating in the project. Restructuring results are presented in the fourth section. The final section offers concluding remarks.

\section{Measures of Enterprise Restructuring}

With what success are Russian firms restructuring? To address this question, one must first decide by what measure restructuring success will be gauged, , and second, how to determine whether

\footnotetext{
${ }^{4}$ Top-level managers in former state-owned firms and in firms that never were state owned were asked about the ongoing operations and performance of their company. Twenty-two questions were the same in both surveys. Data collected from de novo firms are not applied to the composite measures of enterprise restructuring.

${ }^{5}$ Restructuring measures typically include: installation of new director or new management team, profits, sustained or increased production volume, change in the assortment of production (including quality improvements), timely wage payments, payment of above-average wages, absence of barter transactions, foreign capital investment, workforce downsizing equal to or greater than production declines, self-financed investment expenditures, new suppliers and/or new buyers, for example. See Blasi et al (1997), Djankov and Murrell (2000),
} 
enterprise restructuring is "active" (firm-initiated) or "passive" (imposed by economic conditions). Djankov and Murrell (2000) canvassed the transition literature for empirical analyses of enterprise restructuring, dividing the $125+$ papers into two categories: those focusing on quantitative measures of firm performance (volume of output, sales, profits, for example), and those focusing on qualitative measures (timeliness of wage payments, introduction of new products or processes, organizational change, for example). If we take the broadest interpretation of enterprise restructuring - changes which former state-owned enterprises must undertake in order to produce with the requisite degree of efficiency to survive in a market-oriented economy - it is evident that both types of measures are required to evaluate the restructuring success of Russian firms. Both types of measures are problematic, however, because both may reflect demand or market share conditions rather than firminitiated restructuring activities.

This case study of former state-owned enterprises in Taganrog, Russia, utilizes three composite measures to evaluate the nature and scope of enterprise restructuring. The composite measures include both quantitative and qualitative variables. For analytical purposes, the variables included in the composite measures are grouped into three broad categories of restructuring activities: changes in management / organization, changes in production, and changes in employment.

\section{Changes in management / organization}

Several basic themes relating to management change appear in the restructuring literature.

and Linz and Krueger (1998).

6 For example, "active" restructuring might involve a firm changing the size and composition of the workforce in response to profitability considerations arising from production or marketing decisions. Passive restructuring would involve workforce downsizing driven by lack of cash for wage payments. 
First, it is posited that for enterprise restructuring to be successful top-level managers of former state-owned enterprises, the red directors, ${ }^{\square}$ must be removed in order to terminate the Soviet legacy of maximizing output and employment rather than profits (see, for example, Aghion and Blanchard 1996, Claessens and Djankov 1999, Djankov 1999, Frydman, Pistor and Rapaczynski 1996, Pinto, Belka and Krajewski 1993, Roland and Sekkat 2000). Alternatively, for current managers to be successful in the transition and post-transition market-oriented environment, they must receive special training, perhaps even in the West (Dickenson, Campbell and Azarov 2000).

Second, it is posited that re-organization of enterprise operations to accommodate the new economic environment where former state-owned firms must identify and satisfy clients' demands is an integral component of enterprise restructuring (Brown and Earle 1999, Brown and Earle 2000, Brown and Brown 1999, Ickes, Rytermann and Tenev 1995, Joskow, Schmalensee and Tsukanova 1994, Linz and Krueger 1998, McDonald 1993, Shleifer 1998, Svejnar 1996). This is especially important for firms which sell the majority of their product to non-state-owned firms.

Third, a growing literature examines the relationship between ownership structure - insiders (employees) versus outsiders (non-employees) - and enterprise performance, taking the position that enterprise restructuring will be most active when the ownership structure is dominated by outsiders (Aghion and Carlin 1996, Claessens and Djankov 1999a, Earle, Estrin and Leshchenko 1996, Estrin and Rosevear 1999, Frydman Gray, Hessel and Rapaczynski 1999, Jones 1998). It further is posited that if individual insiders (i.e., top-level managers) own substantial blocks of shares (10\% or more), enterprise restructuring is unlikely to be "active".

To utilize management change as a measure of enterprise restructuring, data collected from

\footnotetext{
${ }^{7}$ Term coined by David Granick, The Red Executive (New York: Columbia University Press, 1954).
} 
the former state-owned firms participating in this study focused on whether: (i) the director and/or production manager had been replaced since 1992; (ii) the current director received special training since 1992; (iii) outsiders own more than $25 \%$ of the company's shares; (iv) anyone (insider or outsider) owns a $10 \%$ or more block of shares. While positive responses to these conditions cannot establish the existence of "active" restructuring at the firm, they tend to undermine support for the proposition that firms headed by red directors are continuing to operate in socialist production and employment modes.

\section{Changes in production}

To produce with the requisite degree of efficiency to survive in a market-oriented economy, restructuring of former state-owned enterprises will require changes in the volume and assortment of production. One simple measure of production change compares the current volume of output with that of the previous year. Frequently, however, managers offer information on the value rather than the volume of output, with little explanation of the valuation procedure. Consequently, questions targeted at capacity utilization and how it compares to the previous year are better suited to estimate changes in production. Yet, since both volume and capacity utilization may reflect demand conditions rather than restructuring efforts, neither are well-suited as single measures to evaluate enterprise restructuring.

Change in production assortment frequently is viewed as the key component in enterprise restructuring measures (Blasi et al 1997, Ernst et al 1996, Krueger 1995, Linz and Krueger 1998). Identifying the nature and scope of changes in production assortment incorporates a variety of components: (i) did the firm eliminate any products or services from their assortment; (ii) were existing products improved in any way; (iii) have new products or services (transportation or 
delivery, for example) been added; (iv) has the firm changed suppliers or customers; (v) is the firm currently buying from other firms what it used to self-supply? Production assortment changes also are likely to be associated with the acquisition of new machinery, as well as with expenditures on research and development.

\section{Changes in employment}

Enterprise restructuring involves not only changes in the size and skill composition of the workforce (Clarke 1997, Commander and Coricelli 1995, Konings, Lehman and Schaffer 1996, Konings and Walsh 1999, Linz 2000, World Bank 1996), but also changes in the benefits offered to employees by former state-owned firms (Clarke 1999, Standing 1996). Both of these dimensions are likely to have consequences for the magnitude and timeliness of wage payments, which in turn are correlated with the privatized firm's ability to successfully restructure (Linz and Krueger 1998).

The nature and scope of employment change would be captured, in part, from data collected on the former state-owned firm's current workforce size, the percent of workers released annually since 1992, changes in labor productivity, the percent of current workers who regularly show up for work, and the probability that workers would be released or hired during the current year. In addition, data relating to benefits offered by the privatized firm are relevant. In particular, it is important to know: (i) the number of workers currently receiving benefits and how that compares to the situation in 1992, (ii) the type of benefits currently offered, (iii) how the benefits compare to the size of the wage bill and the firm's profits, (iv) whether nature and scope of benefits have been reduced since 1995, (v) whether any formerly-offered benefits have been transferred to local authorities, and (vi) whether employees pay for benefits.

Wage payment conditions tend to reflect the firm's current financial condition. Whether 
wages are being paid on time, and how the current wage payment situation compares with the previous year, as well as with earlier years reflects on the firm's ability to succeed in Russia's chaotic economic environment, which in turn seems to proxy successful restructuring efforts (Linz and Krueger 1998).

As is evident from the discussion above, no single quantitative or qualitative variable or measure captures the full scope of restructuring efforts that must be undertaken for Russian firms to survive the transition from a planned economy to a market economy. Composite measures which include both quantitative and qualitative variables are more enlightening in terms of the nature and scope of enterprise restructuring, simply because they incorporate more dimensions of the overall undertaking. Moreover, by developing a composite measure, and a simple rule for evaluating success, it is possible to make comparisons across industries and regions. This information is easily digestible by policy makers, should they become inclined to seriously consider ways of improving the economic environment in which Russian firms operate. It is not the case, however, that composite measures are unambiguous in evaluations of the extent of "active" versus "passive" enterprise restructuring in Russia. Composite measures simply serve as a mechanism for identifying a pattern (or lack thereof) in restructuring activities across firms, industries, and regions, as well as over time. Understanding the pattern of restructuring activities makes possible identification of factors which enhance or impede successful restructuring efforts. Establishing a "restructuring threshold" makes it possible to separate former state-owned firms into "winners" and "losers" with regard to adopting changes that will enable them to produce with the requisite degree of efficiency to survive in a market-oriented economy. 


\section{Methodology}

The original research project was designed to investigate enterprise strategies for survival in Russia's transition economy. Since former (and current) state-owned firms inherited a capital stock, workforce, and organizational structure from the Soviet economy, their initial conditions and objective functions are likely to be quite different from firms which never acted as an instrument of central planners or local authorities (Ericson 1996, Ickes and Ericson 2000). Consequently, two questionnaires were developed for the original research project: one to be given to firms that were formerly (or currently) state-owned, and one to be given to firms that had never been state-owned (de novo firms).

To keep the time requirements for completing the questionnaire to a minimum, given the number of questions included in both survey instruments, the majority of questions asked top-level managers to select "yes" or "no," or fill in a number. Twenty-two of the 60+ questions included on each version were identical, yielding a core set of responses relating to the organization and operation of the entire set of participating firms. Data collected from the privatized firms participating in this project are used to construct the composite measures of enterprise restructuring. Where warranted, data collected from the de novo firms will be used to put the restructuring results into a broader perspective. While not strictly a control group, because the de novo firms encompass different sectors of the economy, the comparison is useful for highlighting how Russian firms in general are managing to cope with adverse economic conditions.

To evaluate the nature and scope of enterprise restructuring, three composite measures are developed. For each, the "restructuring threshold" is achieved when the firm responds positively to one-third of the variables included in the composite measure. "Active" (firm-initiated) restructuring 
is designated by positive responses to over $55 \%$ of the variables included in the composite measure. These levels (33\% and 55\%), while arbitrarily established, are based on my observations over the past eight years of nearly 200 firms in Moscow, Novosibirsk, Taganrog and Volgograd. If the levels are set higher (55\% and 75\%), the number of firms designated as restructuring falls (by about half), but the rank order of firms by positive responses remain the same. Regardless of where the levels are set, the composite measures capture the restructuring activities of former state-owned firms more accurately than any single variable.

The first composite measure, Restrct1, focuses exclusively on changes in the assortment of production because of the predominance of this indicator in the restructuring literature. Eighteen variables, equally weighted, are included in Restrct1 (see Table 1). The "restructuring threshold," a positive response to one-third of the variables, is six for Restrct1. "Active" restructuring requires more than ten positive responses. Given that changes in the main assortment of production are less costly the lower the capital intensity of the production process - assortment changes among food processing firms are more easily accomplished than among machine building firms, for example Restrct 1 is likely to be industry-biased with regard to measuring restructuring success.

The second composite measure, Restrct2, designed to capture as broadly as possible the restructuring process, includes a total of thirty-three variables, representing all three categories of restructuring activities: change in management/organization, change in production assortment, and change in employment (see Table 1). As with Restrct1, each variable is given an equal weight. A positive response to eleven of the thirty-three variables puts a firm over the "restructuring threshold." A positive response to more than seventeen variables signals "active" restructuring.

The distribution of variables in Restrct 2 across the three categories of restructuring activities 
is unequal -the number of variables related to changes in production (18) is at least double that of the variables related to changes in employment (9) and changes in management/organization (6). Thus, Restrct 2 is biased in favor of firms that have been active in production changes, which may reflect changes in demand conditions rather than active restructuring efforts, and may, as described above, introduce an industry bias in the evaluation of successful restructuring. Consequently, a third composite measure of restructuring, Restrct3, imposes weights so that each category (management, production, employment) contributes equally to the outcome. In effect, introducing the weights reduces the number of variables, so Restrct3 utilizes the same threshold values as $\boldsymbol{R e s t r c t 1}$ : the "restructuring threshold" is six; "active" restructuring requires a score of ten or more points.

In what way will these composite measures be used? The first objective is to identify the distribution of scores by the privatized firms participating in this project: how many former stateowned firms achieve the "restructuring threshold;" how many fall into the category of "active" restructuring? The second objective is to identify the activities typically associated in the literature with enterprise restructuring that are not common practice among privatized firms. It is important to know, for example, whether or not the majority of privatized firms have replaced top-level managers or discontinued the free provision a wide array of social services to their employees. While a large representative sample of the population of privatized firms in Russia would be invaluable, case study information also is indispensable for evaluating patterns in restructuring activities. The third objective is to identify systematic differences between privatized and de novo firms in response to economic conditions. While de novo firms cannot act as a control group for gauging the restructuring efforts of privatized firms because they incorporate rather different initial conditions and ongoing activities, response patterns from managers of de novo firms help to 
illuminate the economic environment in which Russian firms operate. When designing or adopting policies to improve business conditions, it is important to know, for example, whether response patterns differ significantly between the two types of firms for any given variable influenced by the economic environment. If so, the policy outcome will vary depending upon the relative share of privatized and de novo firms in the community.

\section{Sample Characteristics}

Of the 35 former state-owned firms contacted in the June and October 1999 to participate in this project, ${ }_{32}$ completed at least three-quarters of the designated questionnaire, for a response rate of $91 \%$. The ownership distribution of privatized firms participating in this project includes: 22 registered as joint stock companies (of which 6 were "closed"), 4 registered as privately-owned, and 6 registered as partnership. The industry distribution of these firms includes: 3 in transportation, 4 in construction and construction materials, 10 in heavy industry, 3 in light industry, 6 in food processing, and the remainder in utilities, R\&D, and services. ${ }^{0}$ Workforce size among the participating privatized firms ranged from under 20 employees to over 10,000 employees. Of the twenty-seven firms responding to questions about capacity utilization, 10 nine reported capacity utilization at $50 \%$ or less for the current month; eighteen top-level managers reported capacity utilization exceeding $60 \%$ at the time they completed the questionnaire. In comparison to capacity

\footnotetext{
${ }^{8}$ The population of former state-owned firms in Taganrog was, for the first time in the city's history, available in a telephone directory. About half of the firms were contacted initially by phone; the balance involved an initial contact by person. Assistance with this project was provided by colleagues at Taganrog State University for Radio Engineering.

9 All but one of the former state-owned "service" companies participating in this project are engaged in activities related to Taganrog's sea port.

${ }^{10}$ One question asked the respondent to report the percent of total capacity used by the firm during the current month. A second question asked the respondent to compare the percent of capacity used during the current month with the same month in the previous year.
} 
utilization during the same month in the previous year, nine reported that their current capacity utilization was higher than in the same month in the previous year; two reported lower capacity utilization, fifteen reported the same level of capacity utilization. Sixteen firms reported exporting; of these, eight reported exporting to countries outside the former Soviet Union..

The former state-owned firms participating in the project were not selected to be representative of the population of privatized firms in Russia, or in Taganrog. To conduct such a survey was well beyond the financial resources available for the project. The sample selection objective was to target the inclusion of firms in the following way: one-third from heavy industry, one-third from light industry (including food processing), and one-third from "other industry." More than half of the privatized firms contacted for this project were included because they participated in survey projects I conducted in previous years, and I would like eventually to be able to write up individual case studies of several of these firms. Albeit not necessarily representative, the distribution of privatized firms participating in this project by industry and ownership structure is diverse enough to capture a variety of restructuring activities and survival strategies.

Sample characteristics most informative for this paper are the positive responses by top-level managers of former state-owned enterprises to questions addressing different components of the restructuring process (see Table 1). In terms of production assortment change, for example, just under 40\% reported changing their main assortment of production since 1992 (CHGASRT2). Yet, since 1992, at least half of the former state-owned firms added new products and new buyers. At least half since 1995 added new products (NEWPROD5), new suppliers (NEWCUST5) and obtained

\footnotetext{
${ }^{11}$ Firms were asked first to designate how their totals sales are distributed among buyers in local market and in regional market. Later in the survey instrument, firms were asked what percent of their total sales are within Russia, within the CIS, and to countries outside of the former Soviet Union.
} 
new office equipment (including computers). About $40 \%$ discontinued production of at least one product (STOP92, STOP95). A similar percentage reported adding new suppliers since 1992 (NEWSUP92), although these firms were significantly more likely to have added new suppliers since 1995 (NEWSUP95). Fourteen of sixteen firms responding reported outsourcing their former activities (OURSOURC); that is, buying materials or components from other firms that it used to produce itself. Nearly half of the privatized firms participating in this project obtained new production equipment since 1995 (NEWMCH95). In terms of management/organizational change, about half of the privatized firms experienced turnover in the top-level management positions (NEWBOSS, NEWMGR). One quarter of the managers completing the questionnaire reported receiving specialized training since 1992 for their management position (TRAIN). In more than half of the privatized firms participating in this project, there is at least one block holder (person owning at least $10 \%$ of the company's shares). Fifteen of 18 firms responding reported outsiders (nonemployees) owning shares in the company (OUTSIDER). In terms of changes related to employment, three-quarters of the firms did not expect to release workers in 1999 (RELEASE), nor did they expect to hire additional workers (HIREMORE). Just over $40 \%$ reported labor productivity improvements since 1995.

Former state-owned firms provided the data for the restructuring measures used in this paper, but the research project also involved a survey of 87 de novo firms conducted at the same time in Taganrog. 2 While not strictly a control group, $\frac{13}{2}$ data collected from the de novo firms will be used

${ }^{12}$ Contacts were made by colleagues at Taganrog State University for Radio Engineering, as well as one official from the city administration. I do not know how many de novo firms were contacted about participating in the project, thus I have no concrete information about the response rate.

${ }^{13}$ For example, the privatized firms in this sample, in comparison to the de novo firms: (i) were less likely to be in services/trade; (ii) employed significantly more workers; (iii) reported that a significantly lower 
where warranted to illuminate economic conditions facing Russian firms, as well as to put into perspective the restructuring activities undertaken by former state-owned firms. The industry distribution of the de novo firms participating in the project includes: 6 in construction, ${ }_{4} 7$ in light industry, 5 in food processing, 55 in retail and other services, and the remainder in R\&D. The ownership distribution includes 27 firms registered as privately-owned, 51 firms registered as partnerships, and 7 firms registered as joint stock companies (of which 4 were "closed"). Of the eighty-six firms responding, 63 reported a workforce size of 20 or fewer employees, only three reported a workforce size in excess of 100 employees.

\section{Restructuring with What Success?}

Three composite measures are used here to gauge the relative success of Russian firms in restructuring their operations. The first gives equal weight to 18 variables associated with changes in production assortment (see Restrct1 in Table 1). Using this measure, twenty privatized firms achieved the "restructuring threshold" (positive response to at least 6 questions). This represents over $60 \%$ of the privatized firms participating in the project, and includes: 8 heavy industry firms, 5 food processing firms, 1 light industry firm, 2 construction and construction materials firms, and 3 firms in services. The anticipated industry bias - favoring firms with lower capital intensity - is not evident in Restrct1: all but two of the firms in heavy industry and two of the four firms in

proportion of their workforce showed up regularly for work; (iv) were less likely to be considering hiring additional workers in the coming year; (v) were less likely to pay wages on time; (vi) reported paying a significantly lower percentage of sales revenues to tax authorities; (vii) were more likely to be involved in export activities; (viii) were more likely to have a marketing department; (ix) were more likely to be involved in barter transactions, (x) were headed by significantly older managers; and (xi) were significantly more likely to be adding new products or services. However, there were no significant differences between privatized and de novo firms in terms of recent changes in the volume of activities, or the purchase of new equipment.

\footnotetext{
${ }^{14}$ None of the de novo firms manufactured construction materials.
} 
construction and construction materials achieved the "restructuring threshold;" only one in three of the light industry firms was similarly successful. It is not surprising that the R\&D organizations participating in the project are not included in this composite measure of restructuring. R\&D organizations -especially those which remained in operation at the end of the 1990s -tend to involve low capital intensity but specific human capital. That they are not responding positively to changes in assortment may indicate that they are satisfactorily filling a market niche. Similarly, transportation firms in the 1990s may have faced little need to change their main assortment of services.

Of the twenty privatized firms which achieved the "restructuring threshold," nine attained the "active" restructuring designation, where positive responses to at least 11 questions signal firminitiated restructuring. These include: 4 firms in food processing ( 2 bakeries, 1 fish processing, 1 brewery), 4 firms in heavy industry (of which, two formerly were engaged in defense production, and one supplies materials to the oil industry), $\frac{16}{16}$ and one firm in construction and construction materials supply. Noticeably missing in the "active" restructuring category are the light industry firms participating in this project.

The top three performers with regard to Restrct1, each answering "yes" to 13 of the 18 production assortment change questions, are all in heavy industry; all are open joint stock companies. All report at least one block holder; outsiders own from $30-55 \%$ of the shares in these companies. Employment in these firms ranges from 200 - 10,000 workers. All have experienced top-level

15 Assortment changes by these food processing firms included, for example: developing new types of beer, adding dark bread, buns and cakes, adding non-alcoholic beverages, and adding new canned goods into the production assortment

${ }^{16}$ Assortment changes by heaving industry firms included: construction of road barriers, construction of security gates and security devices, construction of corrosive-proof pipes, bricks manufactured according to 
managerial change. With regard to the restructuring variables, all three report acquiring new production machinery since 1995 , yet they still report the need to renovate between $25 \%$ and $60 \%$ of their capital stock. Despite having vehicles, none of these firms added transportation services since 1992. Differences between these firms arise with regard to outsourcing (2 of 3 do not), discontinuing a product line since 1995 ( 2 of 3 did not), and receiving management training outside of Russia ( 2 of 3 did not). In contrast to other privatized firms participating in this project, these three were less likely to be selling to new buyers or buying from new suppliers.

Regarding changes in production assortment, what is not being done by the thirty-two privatized firms who participated in this project? Given that these firms report needing to renovate on average over $50 \%$ of their capital stock, it is not surprising that less than half of the firms report any change in their main assortment of production; three-quarters report not changing or improving the quality or characteristics of any product in their assortment. Approximately three-quarters of the firms did not eliminate any products from their assortment, although $60 \%$ report adding new buyers. Less than half of the firms reported the acquisition of new production machinery. ${ }^{\square}$ None spent money on research and development in the previous year. Rather surprisingly because of its revenue-generating potential, only two of the thirty-two privatized firms participating in this project reported adding transportation services.

The second composite measure, Restrct 2 , incorporates changes in production, management,

Italian technology, and production of consumer goods, including televisions, for example.

${ }^{17}$ While the correlation coefficient between NEWMCH95 and ELIMPROD is rather low (0.22), there is a stronger correlation (0.46) between the acquisition of new production machinery and improvements in product quality (IMPROVE).

\footnotetext{
${ }^{18}$ This stands in marked contrast to the de novo firms participating in this project $-36 \%$ of these firms added transportation services in the last two years.
} 
and employment, giving equal weight to the thirty-three variables associated with enterprise restructuring (see Table 1). Fourteen of the privatized firms participating in this project achieved the "restructuring threshold" of 11 points. Not surprisingly, given the dominance of production assortment variables and the equal weights assigned to each variable in $\boldsymbol{R e s t r c t} 2$, of the fourteen that achieved the "restructuring threshold" in terms of this broader measure, seven were part of the "active" restructuring group using Restrct1. The newcomers include two companies engaged in activities related to the sea port (ship loading, ship repair), one firm in construction materials, one machine tool firm, one bakery, one firm making electronic devices, and a firm that leases equipment and other materials. All of these firms report at least one block holder; all but two report outsiders owning shares -between $15 \%$ and $55 \%$. All replaced the production manager at least once since 1992; all but one experienced a change in the director since 1992. The majority of these firms have introduced new products, improved the quality of existing products, found new buyers and suppliers, acquired new production machinery and established a marketing department. The majority report timely wage payments. The majority have reduced expenditures on benefits/social services, in part by reducing the range of benefits offered and in part by reducing the number of workers employed to provide these services. 19

Seven firms achieved the "active" restructuring designation using $\boldsymbol{R e s t r c t 2}$. These include three firms in heavy industry, one construction and construction materials firm, one food processing firm, and one firm in services. If these data do reflect the broader population of privatized firms in Russia, the result that less than $25 \%$ of the former state-owned enterprises are actively engaged in restructuring activities does not bode well for the future. Nearly a decade after Russia initiated its

\footnotetext{
${ }^{19}$ The majority of these firms, like the other privatized firms participating in this project, have not transferred benefits to municipal authorities.
} 
transition process to a market-oriented economy, it would still appear that the Soviet legacy is hampering the performance and survival potential of the vast majority of manufacturing firms.

What are the firms who achieved the "restructuring threshold" using Restrct2 not doing in terms of restructuring? The majority, like the rest of the privatized firms participating in this project, have not discontinued a product line, and consequently do not report outsourcing any of their activities. Few are spending on research and development. Half report no labor productivity improvements since 1995, yet more than half are not expecting to release any workers this year. More than half do not charge employees for social services offered by the firm.

In the final composite measure of enterprise restructuring, Restrct3, weights were applied to each of the three categories of restructuring activities (management/organization, production assortment, employment) in order to equalize its contribution to the measure despite the difference in number of variables by category. The objective was to see if the relative performance of the firms with regard to the number achieving the "restructuring threshold" changes from that which emerged when all variables were equally weighted. Because the weighting scheme effectively reduces the number of variables included in the measure, the threshold levels established for Restrct3 equal those of Restrct1 (see Table 1).

Using Restrct3, sixteen firms achieved the "restructuring threshold," exactly half of the former state-owned firms participating in this project. Six are firms in heavy industry, three firms are in food processing, two are in construction and construction materials, two are in light industry, and three are in "other industry and services." emerge using the previous measures: an R\&D organization, a tannery, a transportation firm, and a

\footnotetext{
${ }^{20}$ This category includes firms in transportation, utilities, R\&D and other services.
} 
clothes manufacturer. Indeed, using Restrct3, at least half of the firms in each of the industries included in the sample are engaged in restructuring activities. While the number of firms achieving the restructuring threshold is not significantly greater using Restrct3 than using the previous measures, the composition of firms included in this group is more diverse.

The six firms designated as engaged in "active" restructuring using Restrct3 include three in heavy industry, one in construction and construction materials, one in food processing and one in services. Five of these six emerge at the top of the ranking under Restrct1 and Restrct2, as well. Noticeably absent in any of the "active" restructuring categories are the firms in this sample in light industry and transportation.

What information do we now have about restructuring patterns of former state-owned enterprises? This case study of thirty-two privatized firms in Taganrog, Russia, suggests several patterns. First, when defined broadly to include several dimensions of the restructuring process, the "restructuring threshold" is achieved by half of the privatized firms participating in the project. The firms achieving this threshold are distributed across all industries included in the sample. ${ }^{-1}$ Based on this, I would argue there is no inherent industry bias against restructuring, 22 but that the obstacles facing light industry firms in Russia (consumer attitudes toward Russian-made goods, the availability

${ }^{21}$ This statement is true if utilities firms are included in the category of "other industry and services," rather than as a separate industry. None of the utilities firms scored enough points to achieve the "restructuring threshold" using any of the composite measures.

${ }^{22}$ Using probit regression analysis, with CHGASRT5 (CHGASRT2) as the dependent variable for 1995 (1992) and dummy variables for each industry as the independent variables, it is the case that when using the heavy industry firms in this sample as the comparison group, there are no significant differences by industry in either year. Moreover, in terms of the response patterns by managers to the question involving the percentage of their capital stock that needs renovating, there also are no significant industry differences. That is, when RENOVATE is the dependent variable, and dummy variables for each industry are the independent variables, with heavy industry firms are the comparison group, no industry emerges as better or worse off than heavy industry. 
of cheap imports, for example) may be more severe than for other industries. 23 If the "restructuring threshold" is raised from $33 \%$ to $55 \%$, for example, the light industry firms no longer are included in the restructuring group.

Second, regardless of the composite measure used, more than one-third of the former stateowned firms who reached the "restructuring threshold" also attained the "active" restructuring designation. Is the "active" restructuring threshold (55\% positive responses required) too low? Raising it from $55 \%$ to $75 \%$ reduces the number of firms attaining the designation, but it is still the case that at least two of thirty-two former state-owned firms achieve this higher threshold level: using Restrct1, one firm in producing steel pipes, one firm producing machine tools are included in the "winning" group; using Restrct2, the steel pipe manufacturer and a construction and construction materials company are included; using Restrct3, these same two firms, plus a machine tools firm are included in the "winning" group. What is to be gained from raising the threshold? Raising the "active" restructuring threshold from $55 \%$ to $75 \%$ eliminates from the "winning" group at least three former state-owned firms that I know, based on numerous on site visits and in-depth interviews, have undertaken firm-initiated changes over the past eight years to improve the operation and performance of the company. Raising the threshold provides a more conservative estimate of the number of firms actively engaged in restructuring activities, but I do not think the estimate is more accurate than that

\footnotetext{
${ }^{23}$ A measure of the severity of the impact by industry involves changes in workforce size. All data suggest that Russian firms were reluctant to release workers in the early stage of the transition process (see Goskomstat 1999, Standing 1996, Clarke 1998, for example). In this project, respondents were asked to report the percentage of their workforce released in 1992, and a separate question later in the survey instrument asked them to report the percentage of their workforce released in 1997. The light industry firms participating in this project released a significantly greater share of their workers in 1992 than any other industry group in the sample; there were no significant industry differences for 1997.

${ }^{24}$ Nine of 20 firms (45\%) attained "active" restructuring designation using Restrct1; seven of 14 firms (50\%) using Restrct2; six of 16 firms (38\%) using Restrct3.
} 
which emerges when the threshold is set at $55 \%$.

Third, production assortment changes appear to be ongoing among those firms engaged in restructuring activities: all firms that achieved the "restructuring threshold" using Restrct3 who reported assortment changes since 1995 (CHGASRT5) also reported assortment changes in 1992 (CHGASRT2). ${ }^{25}$ No significant difference by industry emerges with regard to this result. ${ }^{26}$ It does not appear to be the case, however, that changes in the main assortment of production are highly correlated with product termination. 27 More highly correlated to assortment changes are the introduction of a new product (the correlation coefficient is 0.56 between CHGASRT2 and NEWPROD $2 ;$ the correlation coefficient between CHGASRT5 and NEWPROD5 is 0.60), and the hiring of a new production manager ( 0.43 for assortment changes in 1992 and 0.49 for those taking place since 1995).

Fourth, employment changes appear to involve a mixed strategy with regard timely wage payments, workforce size, and the benefits package. For example, even among the firms achieving the "restructuring threshold" using Restrct3, one-quarter were not up-to-date with regard to wage payments; although half of these firms reported an improved situation with regard to wage arrears in comparison to 1995 . There was no significant difference between the firms achieving the

\footnotetext{
${ }^{25}$ For all privatized firms participating in this project, the correlation coefficient between production assortment change in 1995 and 1992, CHGASRT2 and CHGASRT5, is 0.93.

${ }^{26}$ The only industry effect that emerges with regard to production assortment changes is when CHGASRT2 is used as the dependent variable, and dummy variables for industries included in the sample are used as the independent variables, with "other industry and services" used as the comparison group. In this situation, food processing firms are significantly more likely to respond positively to assortment changes in 1992.

${ }^{27}$ The correlation coefficient between change assortment in 1992 and stop product in 1992 is 0.38 ; for 1995 , the correlation coefficient between these to variables is 0.17 .

${ }^{28}$ Interestingly enough, the correlation between change assortment in 1992 and the percent of workforce released in 1992 is -0.32 .
} 
"restructuring threshold" using Restrct3 and those who did not in terms of the percent of their workforce that was released in 1992 (on average, 22\% and 24\%, respectively), or in 1997 (7\% and 5\%, respectively). Fifteen of the 16 firms achieving the "restructuring threshold" using $\operatorname{Restrct} 3$ did not transfer benefits to local authorities to provide. "restructuring threshold" using Restrct3 reduced the number of employees engaged in the provision of benefits/social services; half require employees to pay for benefits; over two-thirds reduced spending, in real terms, on benefits to workers since 1995 . There are no discernable industry or ownership differences in these results.

Finally, outsider ownership is more prevalent among the group of firms designated as restructuring than among those firms that failed to achieve the "restructuring threshold." That is, among the firms achieving the "restructuring threshold" using Restrct3, outsiders own 50\% of the transportation company, $10 \%$ of the service company and one of the construction companies (the second is privately-owned). Outsiders are reported to own $15 \%$ of one heavy industry company, $30 \%$ of a second heavy industry company, and $55 \%$ of the third heavy industry company included in the restructuring group. Both the light industry and food processing firms report $15 \%$ outside ownership. The R\&D firm reports no outside owners. In only four of the eleven firms below the “restructuring threshold" using Restrct3 that answered the question was an outside owner reported. Regarding the concentration of shares, while half of the privatized firms participating in the project report at least one block holder, among the firms achieving the "restructuring threshold" using

\footnotetext{
${ }^{29}$ None of the firms below the "restructuring threshold" did so.

${ }^{30}$ Among all the privatized firms answering this question, outside ownership averaged $15 \%$ for the restructuring firms, and $7 \%$ for the non-restructuring firms.
} 
Restrct3, more than two-thirds report at least one block holder. 1

Having identified and analyzed the firms achieving the restructuring threshold, the third objective addressed by this case study is: How do privatized firms compare with de novo firms in terms of changes in organization, operations, and employment?

Regarding organizational changes, the most striking difference is the addition of transportation services: $36 \%$ of the de novo firms compared to $6 \%$ of the privatized firms added transport services to their range of activities. De novo firms were less likely to have a marketing department: $25 \%$ compared to $38 \%$ of the privatized firms. For firms participating in this project, the existence of a marketing department is positively correlated to the export experience of the firm. ${ }^{22}$ For privatized firms, the correlation coefficient between export experience and having a marketing department is 0.58 (for exports outside of the former Soviet Union) or 0.74 (for exports outside of Russia); for de novo firms, the correlation coefficients are 0.03 and 0.16 , respectively.

Regarding changes in operations, fifteen of the twenty-seven privatized firms responding to the question reported capacity utilization the same in 1999 as in the comparable month in 1998; onethird reported a decline in capacity utilization. In contrast, one-third of the de novo firms participating in this project reported an increase in the volume of operations in comparison to the same month in 1998. One quarter reported a comparable level of operations. Thirty-three de novo firms reported their volume of operations to be lower in 1999 than during the comparable month in 1998. De novo firms were no more likely than privatized firms to add new services or activities

${ }^{31}$ Of the five restructuring firms that did not report block holder, three are in heavy industry, one is in light industry, and one is in food processing.

32 That is, $25 \%$ of the privatized firms participating in this project reported exporting products outside of the former Soviet Union; 57\% exported outside of Russia. Among privately-owned firms, the comparable figures are $11 \%$ and $24 \%$, respectively. 
( $51 \%$ compared to $55 \%$ since 1992 or $48 \%$ since 1995), but were significantly more likely to be adding new suppliers (67\% compared to $48 \%$ ), new buyers ( $82 \%$ compared to $59 \%$ ), and new equipment (64\% compared to 47\%). Interestingly enough, the de novo firms were even less likely than privatized firms participating in this project to discontinue products or services ( $24 \%$ compared to $39 \%$ ).

Regarding changes in employment, it is first important to note the relative size of the privatized and de novo firms participating in this project. The former employ on average 781 workers; the latter, 25 workers. Among privatized firms, the mean response by the top-level managers completing the questionnaire was that over $85 \%$ of their employees show up regularly for work. Correspondingly, according to the de novo firms participating in this project, $95 \%$ of their employees show up regularly for work. While $22 \%$ of the privatized firms were planning to hire additional workers in $1999,41 \%$ of the de novo firms had plans to do so. Ten percent of the de novo firms compared to $25 \%$ of the privatized firms expected to release workers. While there was a significant difference between the responses of managers in the privatized and de novo firms in the reported timeliness of wage payments to employees $-59 \%$ of privatized firms reported no wage delays, $88 \%$ of the de novo firms report timely wage payments -there was no significant difference between them in terms of their response patterns to providing benefits to employees: just over a third responded affirmatively. Managers of de novo firms were significantly younger and significantly more likely to have received specialized training (37\%) than managers of privatized firms $(25 \%)$, although managers of privatized firms, if they received training, were more likely to have participated in training programs outside of Russia (10\% compared to $5 \%$ of the mangers of the de novo firms participating in this project). 
While differences outnumber similarities between the privatized and de novo firms participating in this project, it remains instructive to compare the operation and performance of both types of firms in order to obtain a broader picture of the economic conditions and business environment in Russia.

\section{Conclusions}

This case study of thirty-two former state-owned enterprises in Taganrog, Russia, utilizes three composite measures to gauge the relative success of their restructuring efforts. When a "restructuring threshold" of $33 \%$ positive responses is applied to the broadest composite measure, Restrct3, half of the privatized firms participating in this project achieved the threshold level. These include firms from each industry included in the project: heavy industry, light industry, food processing, transportation, construction and construction materials, and "other industry and services." Yet, less than $20 \%$ of the former state-owned firms attained the "active" restructuring designation. That is, fewer than one in five firms participating in this project responded positively to over $55 \%$ of the requisite questions. Firm-initiated restructuring, while occurring among firms in heavy industry, food processing, construction and construction materials, and services, was not typical among the former state-owned enterprises in this case study. This result is hardly surprising, given the aggregate data describing production, investment and employment throughout the 1990s, as well as what is known about the legal and financial environment in which Russian firms operate.

While this case study is not at odds with the larger picture of enterprise restructuring and economic transition in Russia, these data and results do much more than simply confirm what we 
already know. The case study results indicate, for example, that among the former state-owned enterprises participating in this project, ownership structure differs significantly between the firms that are restructuring and firms that are not: firms engaged in restructuring are more likely to have outsiders own shares, and are more likely to have at least one block holder. With regard to production assortment changes, restructuring firms are more likely to have introduced new products, added new buyers and suppliers, and acquired new production equipment than firms not engaged in restructuring. Moreover, production assortment changes appear to be ongoing for those firms that achieved the "restructuring threshold." Finally, firms achieving the "restructuring threshold" are more likely to have reduced the range of benefits offered to employees, as well as to have reduced the number of employees engaged in the provision of social services at the firm. Only one of these firms, however, reports transferring to local authorities at least some portion of the social services formerly offered by the firm.

The case study results also indicate a number of areas where restructuring firms might still need to devote more attention. For example, firms achieving the "restructuring threshold" reported not experiencing labor productivity improvements since 1995, yet they are not necessarily more likely to report plans to release workers than other privatized firms participating in this project. Moreover, they are not any more likely to charge employees for social services offered by the company. Nor do they report discontinuing the production of a product line or service.

When asked what they would need to successfully restructure their firm, top-level managers report "money." While money would certainly be helpful, it appears to me that the Soviet production and employment legacy are still strong enough among former state-owned enterprises to undermine the effective utilization of additional financial resources. Moreover, all firms 
participating in this project, privatized and de novo alike, reported obstacles imposed by the federal (including customs) bureaucracy, the tax system, the inadequate enforcement of existing laws, as well as by ineffective and inappropriate regulations and inspections, and corruption as more problematic than financing in terms of their operations and performance. 


\section{References}

Aghion, Philippe and Olivier Blanchard. 1996. "On Insider Privatization," European Economic Review vol 40, no 5 (April), pp. 759-66.

Aghion, Philippe and Wendy Carlin. 1996. "Restructuring Outcome and the Evolution of Ownership Patterns in Central and Eastern Europe," Economics of Transition, vol 4, no 2 (October), pp. 371-88.

Barberis, Nicholas et al. 1996. "How Does Privatization Work? Evidence from the Russian Shops," Journal of Political Economy, vol 194, no 4 (August), pp. 764-90.

Belka, Marek et. al. 1994. "Enterprise Adjustment in Poland: Evidence from a Survey of 200 Private, Privatized and State Owned Firms," London School of Economics, Working Paper \#47, Center for Economic Performance.

Blasi, Joseph et. al. 1997. Kremlin Kapitalism (Ithaca NY: Cornell University Press).

Boycko, Maxim et. al. 1995. Privatizing Russia (Cambridge MA: MIT Press).

Brown, Annette and David Brown. 1999. "Does Market Structure Matter? New Evidence from Russia," CEPR Discussion paper (April).

Brown, David and John Earle. 1999. "Privatization and Enterprise Restructuring in Russia: New Evidence from Panel Data on Industrial Enterprises," SITE, Stockholm School of Economics (December).

Brown, David and John Earle. 2000. "Competition and Firm Performance: Lessons from Russia," SITE, Stockholm School of Economics (March).

Buck, Trevor, Igor Filatotchev and Mike Wright. 1994. "Employee Buyouts and the Transformation of Russian Industry," Comparative Economic Studies, vol 36, no 2 (Summer), pp. 1-16.

Chichilyimov, Vladimir. 1999. Energiya sotsial'nogo bitiya naseleniya srednego goroda Rossii na proroge 21 veka (Taganrog: Izdatel'stvo TRTY).

Clarke, Simon (ed.). 1997. The Russian Enterprise in Transition (Brookfield MA: Edward Elgar).

Clarke, Simon. 1999. The Formation of A Labour Market in Russia (New York: Edward Elgar). 
Claessens, Stijn and Simeon Djankov. 1999. "Enterprise Performance and Management Turnover in the Czech Republic," European Economic Review, vol 43, no 4-6 (April), pp. 1115-1124.

Commander, Simon and Fabrizio Coricelli (eds.). 1995. Unemployment, Restructuring and the Labor Market in Eastern Europe and Russia (Washington D.C.: World Bank).

Commander, Simon et al. 1996. Enterprise Restructuring and Economic Policy in Russia (Washington D.C.: World Bank).

Dickenson, R. Peter et. al. 2000. "Will Western Managerial Methods Work in Transitional Societies?" Problems of Post-Communism, vol 47, no 23 (May/June), pp. 48-56.

Djankov, Simeon. 1999. "Restructuring of Insider-Dominated Firms," Economics of Transition vol 7, no 2 (June), pp. 467-479.

Djankov, Simeon. 1999. "Ownership Structure and Enterprise Restructuring in Six Newly Independent States," Comparative Economic Studies vol 41, no 1 (Winter), pp. 75-95.

Djankov, Simeon and Peter Murrell. 2000. "Enterprise Restructuring in Transition: A Quantitative Survey," unpublished manuscript, University of Maryland (April).

Dolgopyatova, Tat'yana. 1995. Rossiyskiye predpriyatiya v perekhodnoy ekonomiki (Moscow: Delo Publishers).

. Earle, John and Saul Estrin.1997. "After Voucher Privatization: The Structure of Corporate Ownership in Russian Manufacturing Industry,"SITE Working Paper, no 120 (Stockholm Institute of Transition Economies).

Earle, John, Saul Estrin, and Larisa Leshchenko. 1996. “Ownership Structures, Patterns of Control, and Enterprise Behavior in Russia,"in Commander et al, Enterprise Restructuring and Economic Policy in Russia, pp. 205-52.

Ericson, Richard. 1996. "Restructuring and Industry During Transition: A Two Period Model," Columbia University, Economics Department Discussion Paper Series, no 9697-03 (September).

Ericson, Richard. 1998. "Restructuring in Transition: Concept and Measurement: Discussion," Comparative Economic Studies, vol 4, no 2 (Summer), pp. 103-108.

Ernst, Maurice, Michael Alexeev and Paul Marer. 1996. Transforming the Core: Restructuring Industrial Enterprises in Russia and Central Europe (Boulder: Westview Press). 
Estrin, Saul and Adam Rosevear. 1999. "Enterprise Performance and Corporate Governance in the Ukraine," Journal of Comparative Economics vol 27, no 3 (September), pp. 442458.

Frydman, Roman, Cheryl Gray, and Andrej Rapaczynski (eds.). 1990. Corporate Governance in Central Europe and Russia vol. 2 (Budapest: Central European University Press).

Frydman, Roman, Cheryl Gray, Marek Hessel, and Andrej Rapaczynski 1999. "When Does Privatization Work? The Impact of Private Ownership and Hard Budget Constraints in the Transition Economies," New York University Working Paper (NYU).

Frydman, Roman, Katarina Pistor and Andrej Rapaczynski. 1996. "Exit and Voice after Mass Privatization: The Case of Russia," European Economic Review vol 40, no 2-3, (April), pp. 581-588.

Grushin, Boris. 1980. Massovaya informatsiya v sovetskom prom'shlyennom gorod (Moscow: Izdatel'stvo politicheskoi literaturi).

Hendley, Kathryn, Barry Ickes and Randi Ryterman. 1997. "Observations on the Use of Law by Russian Enterprises," Post-Soviet Affairs vol 13, no 2 (January-March), pp. 19-41.

Ickes, Barry and Richard Ericson. 2000. "Modeling the Virtual Economy," mimeo.

Ickes, Barry and Clifford Gaddy. 1998. “To Restructure of Not to Restructure: Informal Activities and Enterprise Behavior in Transition," mimeo (February).

Ickes, Barry and Clifford Gaddy. 1999. "A Simple Four Sector Model of the Virtual Economy," Post-Soviet Geography and Economics, vol.40, 2 (February), 123-239.

Ickes, Barry and Randi Ryterman and Stoyan Tenev. 1995. "On Your Marx, Get Set, Go: The Role of Competition in Enterprise Adjustment," mimeo June (Washington D.C. :World Bank).

Jones, Derek. 1998. "The Economic Effects of Privatization: Evidence from a Russian Panel," Comparative Economic Studies, vol 40, no 2 (Summer), pp. 75-102.

Joskow, Paul et. al. 1994. "Competition Policy in Russia During and After Privatization," Brookings Papers on Economic Activity, vol 24, no 1 (June), pp. 301-84.

Konings, Jozef et al. 1996. "Job Creation and Job Destruction in a Transition Economy," Labour Economics, vol 3 no 3 (October), pp. 299-317.

Konings, Jozef and Patrick Walsh. 1999. "Employment Dynamics of Newly Established and Traditional Firms: A Comparison of Russia and the Ukraine," LICOS Discussion Paper 
81, Katholieke Universiteit, Leuven.

Krueger, Gary. 1995. "Transition Strategies of Former State-Owned Firms in Russia," Comparative Economic Studies, vol 37, no 4 (Winter), pp. 1-18.

Linz, Susan J. 1995. "Russian Labor Market in Transition," Economic Development and Cultural Change vol 43, no 4 (July), pp. 693-716.

Linz, Susan J. 1997. "Russian Firms in Transition: Champions, Challengers, and Chaff," Comparative Economic Studies vol 39, no 2 (Summer), pp. 1-36.

Linz, Susan J. 1998. "Job Rights in Russian Firms: Endangered or Extinct Institution?" Comparative Economic Studies vol 40, no 4 (Winter), pp. 1-32.

Linz, Susan J. 1999. "Who is Shouldering the Burden of Transition? An Analysis of Depreciation Rates in Russian Industry," Comparative Economic Studies, vol 41, no 2-3 (Summer/Fall), pp. 1-44.

Linz, Susan J. 2000. "Labor Productivity in Transition: A Regional Analysis of Russian Industry," Economic Development and Cultural Change (forthcoming).

Linz, Susan J. and Jeff E. Biddle.1998. "Innovation in Russian Industry: A Case Study of R\&D in Transition," Economic Development and Cultural Change vol 46, no 2 (January), pp. 233-262.

Linz, Susan J. and Gary Krueger. 1998. "Enterprise Restructuring in Russia's Transition Economy: Formal and Informal Mechanisms," Comparative Economic Studies, vol 40, no 2 (Summer), pp. 5-52.

McDonald, Kevin. 1993. "Why Privatization is Not Enough," Harvard Business Review (MayJune), pp. 49-59.

Nelson, Lynn and Irma Kuzes. 1994. "Evaluating the Russian Voucher Privatization Program," Comparative Economic Studies, vol 36, no1 (Spring), pp. 55-68.

Perevalov, Yu, I. Gimadi and V. Dobrodei. 1999. "Vliiaet li privatizatsiia na deiatel'nost' predpriiatii?" Voprosy ekonomiki no 6 , pp. 76-89.

Pinto, Brian, Marek Belka and Stefan Krajewski.1993. "Transforming State Enterprises in Poland: Evidence on Adjustment by Manufacturing Firms," Brookings Papers on Economic Activity no 1, pp. 213-270.

Rimashevskaya, Natalyia. 1992. Taganrog Studies: Family Well-Being, Conditions, Standards, Way and Quality of Life of the Population of Russia (Moscow: Institute for 
Socio-Economic Studies of the Population).

Roland, Gerard. 1994. "On the Speed and Sequencing of Privatization and Restructuring," Economic Journal, vol 104, no 426 (September), pp. 1158-1168.

Roland, Gerard and Khalid Sekkat. 2000. "Managerial Career Concerns, Privatization and Restructuring in Transition Economies," European Economic Review (forthcoming).

Shleifer, Andrei. 1998. "State versus Private Ownership,” Journal of Economic Perspectives vol 12, no 4 (Fall), pp. 133-50.

Standing, Guy. 1996. Enterprise Restructuring and Russian Unemployment: Reviving Dead Souls (Basingstoke UK: Macmillan).

Svejnar, Jan. 1996. "Enterprises and Workers in Transition: Econometric Evidence," American Economic Review, Papers and Proceedings, vol 86, no 2 (May), pp. 123-127.

World Bank. 1996. From Plan to Market (Oxford). 



\section{Table 1: Composite Measures of Enterprise Restructuring}

Index 1

CHGASRT2

ELIMPROD

IMPROVE

NEWPROD2

TRNZPRT1

STOP92

NEWSUP92

NEWCUST2

CHGASRT5

NEWPROD5

STOP95

MKTGDEPT

NEWMCH95

COMPUTR5

RDNOW

OUTSOURC

NEWSUP95

NEWCUST5

Index 2

NEWBOSS

NEWMGR

TRAIN

WEST

BLOCK

OUTSIDER

\section{Production Assortment Change}

$\%$ Yes

$N$

Has the company changed the main assortment of production since 1992 ?

Has company eliminated one or more products since 1992 ?

Has the company changed or improved quality or characteristics of product since 1992 ?

Has the company added new products since 1992 ?

Has the company added transport services or changed transport activities since 1992?

Has the company discontinued production of any products since 1992 ?

Has company added new suppliers since 1992 ?

Has company added new customers (buyers) since 1992?

Has the company changed the main assortment of production since 1995 ?

Has the company added new products since 1995 ?

Has the company discontinued production of any products since 1995? 39

Does company have a marketing department?

Has company obtained new production equipment since 1995 ?

obtained other new equipment - office equipment, computer - since 1995?

This year, is the company spending money on research and development?

Does the company now buy materials or components that it used to produce itself?

Has company added new suppliers since 1995 ?

Has company added new customers (buyers) since 1995?

Management / Organizational Change

$\%$ Yes $\quad N$

Has the company replaced or acquired a new director since 1992 ?

Has the production manager been replaced since 1992?

Since 1992, have you received specialized training for this job as manager/director?

Have you received management training outside of Russia?

Does anyone own a block of shares - 10\% or more shares owned by 1 person/organization?

Do non-employees -outsiders -own shares in this company? 
RELEASE

HIREMORE

PRODUP95

BENEFITS

TRANSFRB

FEEFORB

REDUCEB5

REDUCEB2

PAYWAGE

\section{Restrct1}

Restrct2

Restrct3
Do you (does the company) expect to release workers this year?

$25 \quad 32$

Does the company expect to hire additional workers this year?

Has labor productivity improved since 1995 ?

Does the company offer employees any social services or benefits?

Has the company transferred social services to municipal authorities since 1992 ?

Has the company transferred expenses for social services to employees; that is, the company still provides the service or benefit, but employees must pay for the service or benefit?

Since 1995, after adjusting for inflation, has the company reduced spending on social services?

Has the company reduced the number of social service employees since 1992 ?

Is the company up to date in payment of wages to workers?

$23 \quad 31$

$47 \quad 30$

\section{Index 1, equal weight on all 18 variables}

Number of firms scoring < 6

Number of firms scoring $6-10$

Number of firms scoring $>10$

Sum of Index 1-3, equal weight on all 33 variables

Number of firms scoring $<11$

Number of firms scoring 11- 17

Number of firms scoring $>17$

Sum of Index 1-3, each index with equal weight

Number of firms scoring $<6$

Number of firms scoring $6-10$

Number of firms scoring $>10$ 



\section{DAVIDSON INSTITUTE WorkING PAPER SERIES}

CURRENT AS OF 7/21/00

\begin{tabular}{|c|c|c|}
\hline Publication & Authors & Date of Paper \\
\hline $\begin{array}{l}\text { No. } 324 \text { Restructuring with What Success? A } \\
\text { Case Study of Russian Firms }\end{array}$ & Susan Linz & July 2000 \\
\hline $\begin{array}{l}\text { No. } 323 \text { Priorities and Sequencing in } \\
\text { Privatization: Theory and Evidence from the } \\
\text { Czech Republic }\end{array}$ & $\begin{array}{l}\text { Nandini Gupta, Joh C. Ham and Jan } \\
\text { Svejnar }\end{array}$ & May 2000 \\
\hline $\begin{array}{l}\text { No. } 322 \text { Liquidity, Volatility, and Equity } \\
\text { Trading Costs Across Countries and Over } \\
\text { Time }\end{array}$ & $\begin{array}{l}\text { Ian Domowitz, Jack Glen and Ananth } \\
\text { Madhavan }\end{array}$ & March 2000 \\
\hline $\begin{array}{l}\text { No. } 321 \text { Equilibrium Wage Arrears: } \\
\text { Institutional Lock-In of Contractual Failure in } \\
\text { Russia }\end{array}$ & John S. Earle and Klara Z. Sabirianova & June 2000 \\
\hline $\begin{array}{l}\text { No. } 320 \text { Rethinking Marketing Programs for } \\
\text { Emerging Markets }\end{array}$ & Niraj Dawar and Amitava Chattopadhyay & June 2000 \\
\hline $\begin{array}{l}\text { No. } 319 \text { Public Finance and Low Equilibria in } \\
\text { Transition Economies; the Role of Institutions }\end{array}$ & Daniel Daianu and Radu Vranceanu & June 2000 \\
\hline $\begin{array}{l}\text { No. } 318 \text { Some Econometric Evidence on the } \\
\text { Effectiveness of Active Labour Market } \\
\text { Programmes in East Germany }\end{array}$ & Martin Eichler and Michael Lechner & June 2000 \\
\hline $\begin{array}{l}\text { No. } 317 \text { A Model of Russia's "Virtual } \\
\text { Economy" }\end{array}$ & R.E Ericson and B.W Ickes & May 2000 \\
\hline $\begin{array}{l}\text { No. } 316 \text { Financial Institutions, Financial } \\
\text { Contagion, and Financial Crises }\end{array}$ & Haizhou Huang and Chenggang Xu & March 2000 \\
\hline $\begin{array}{l}\text { No. } 315 \text { Privatization versus Regulation in } \\
\text { Developing Economies: The Case of West } \\
\text { African Banks }\end{array}$ & $\begin{array}{l}\text { Jean Paul Azam, Bruno Biais, and } \\
\text { Magueye Dia }\end{array}$ & February 2000 \\
\hline $\begin{array}{l}\text { No. } 314 \text { Is Life More Risky in the Open? } \\
\text { Household Risk-Coping and the Opening of } \\
\text { China's Labor Markets }\end{array}$ & John Giles & April 2000 \\
\hline $\begin{array}{l}\text { No. } 313 \text { Networks, Migration and Investment: } \\
\text { Insiders and Outsiders in Tirupur's } \\
\text { Production Cluster }\end{array}$ & Abhijit Banerjee and Kaivan Munshi & March 2000 \\
\hline $\begin{array}{l}\text { No. } 312 \text { Computational Analysis of the Impact } \\
\text { on India of the Uruguay Round and the } \\
\text { Forthcoming WTO Trade Negotiations }\end{array}$ & $\begin{array}{l}\text { Rajesh Chadha, Drusilla K. Brown, Alan } \\
\text { V. Deardorff and Robert M. Stern }\end{array}$ & March 2000 \\
\hline $\begin{array}{l}\text { No. } 311 \text { Subsidized Jobs for Unemployed } \\
\text { Workers in Slovakia }\end{array}$ & Jan. C. van Ours & May 2000 \\
\hline $\begin{array}{l}\text { No. } 310 \text { Determinants of Managerial Pay in } \\
\text { the Czech Republic }\end{array}$ & $\begin{array}{l}\text { Tor Eriksson, Jaromir Gottvald and Pavel } \\
\text { Mrazek }\end{array}$ & May 2000 \\
\hline $\begin{array}{l}\text { No. } 309 \text { The Great Human Capital } \\
\text { Reallocation: An Empirical Analysis of } \\
\text { Occupational Mobility in Transitional Russia }\end{array}$ & Klara Z. Sabirianova & May 2000 \\
\hline $\begin{array}{l}\text { No. } 308 \text { Economic Development, Legality, and } \\
\text { the Transplant Effect }\end{array}$ & $\begin{array}{l}\text { Daniel Berkowitz, Katharina Pistor, and } \\
\text { Jean-Francois Richard }\end{array}$ & February 2000 \\
\hline
\end{tabular}




\begin{tabular}{|c|c|c|}
\hline $\begin{array}{l}\text { No. } 307 \text { Community Participation, Teacher } \\
\text { Effort, and Educational Outcome: The Case of } \\
\text { El Salvador's EDUCO Program }\end{array}$ & Yasuyuki Sawada & November 1999 \\
\hline $\begin{array}{l}\text { No. } 306 \text { Gender Wage Gap and Segregation } \\
\text { in Late Transition }\end{array}$ & Stepan Jurajda & May 2000 \\
\hline $\begin{array}{l}\text { No. } 305 \text { The Gender Pay Gap in the } \\
\text { Transition from Communism: Some Empirical } \\
\text { Evidence }\end{array}$ & Andrew Newell and Barry Reilly & May 2000 \\
\hline $\begin{array}{l}\text { No. } 304 \text { Post-Unification Wage Growth in } \\
\text { East Germany }\end{array}$ & Jennifer Hunt & November 1998 \\
\hline $\begin{array}{l}\text { No. } 303 \text { How Does Privatization Affect } \\
\text { Workers? The Case of the Russian Mass } \\
\text { Privatization Program }\end{array}$ & Elizabeth Brainerd & May 2000 \\
\hline $\begin{array}{l}\text { No. } 302 \text { Liability for Past Environmental } \\
\text { Contamination and Privatization }\end{array}$ & Dietrich Earnhart & March 2000 \\
\hline No. 301 Varieties, Jobs and EU Enlargement & Tito Boeri and Joaquim Oliveira Martins & May 2000 \\
\hline No. 300 Employer Size Effects in Russia & Todd Idson & April 2000 \\
\hline $\begin{array}{l}\text { No. } 299 \text { Information Complements, } \\
\text { Substitutes, and Strategic Product Design }\end{array}$ & $\begin{array}{l}\text { Geoffrey G. Parker and Marshall W. Van } \\
\text { Alstyne }\end{array}$ & March 2000 \\
\hline $\begin{array}{l}\text { No. } 298 \text { Markets, Human Capital, and } \\
\text { Inequality: Evidence from Rural China }\end{array}$ & $\begin{array}{l}\text { Dwayne Benjamin, Loren Brandt, Paul } \\
\text { Glewwe, and Li Guo }\end{array}$ & May 2000 \\
\hline $\begin{array}{l}\text { No. } 297 \text { Corporate Governance in the Asian } \\
\text { Financial Crisis }\end{array}$ & $\begin{array}{l}\text { Simon Johnson, Peter Boone, Alasdair } \\
\text { Breach, and Eric Friedman }\end{array}$ & November 1999 \\
\hline $\begin{array}{l}\text { No. } 296 \text { Competition and Firm Performance: } \\
\text { Lessons from Russia }\end{array}$ & J. David Brown and John S. Earle & March 2000 \\
\hline $\begin{array}{l}\text { No. } 295 \text { Wage Determination in Russia: An } \\
\text { Econometric Investigation }\end{array}$ & Peter J. Luke and Mark E. Schaffer & March 2000 \\
\hline $\begin{array}{l}\text { No. 294: Can Banks Promote Enterprise } \\
\text { Restructuring?: Evidence From a Polish } \\
\text { Bank's Experience }\end{array}$ & John P. Bonin and Bozena Leven & March 2000 \\
\hline $\begin{array}{l}\text { No. 293: Why do Governments Sell Privatised } \\
\text { Companies Abroad? }\end{array}$ & $\begin{array}{l}\text { Bernardo Bortolotti, Marcella Fantini and } \\
\text { Carlo Scarpa }\end{array}$ & March 2000 \\
\hline $\begin{array}{l}\text { No. 292: Going Public in Poland: Case-by- } \\
\text { Case Privatizations, Mass Privatization and } \\
\text { Private Sector Initial Public Offerings }\end{array}$ & Wolfgang Aussenegg & December 1999 \\
\hline $\begin{array}{l}\text { No. 291: Institutional Technology and the } \\
\text { Chains of Trust: Capital Markets and } \\
\text { Privatization in Russia and the Czech } \\
\text { Republic }\end{array}$ & Bruce Kogut and Andrew Spicer & March 1999 \\
\hline $\begin{array}{l}\text { No. 290: Banking Crises and Bank Rescues: } \\
\text { The Effect of Reputation }\end{array}$ & Jenny Corbett and Janet Mitchell & January 2000 \\
\hline $\begin{array}{l}\text { No. 289: Do Active Labor Market Policies } \\
\text { Help Unemployed Workers to Find and Keep } \\
\text { Regular Jobs? }\end{array}$ & Jan C. van Ours & February 2000 \\
\hline $\begin{array}{l}\text { No. 288: Consumption Patterns of the New } \\
\text { Elite in Zimbabwe }\end{array}$ & Russell Belk & February 2000 \\
\hline $\begin{array}{l}\text { No. 287: Barter in Transition Economies: } \\
\text { Competing Explanations Confront Ukranian } \\
\text { Data }\end{array}$ & $\begin{array}{l}\text { Dalia Marin, Daniel Kaufmann and } \\
\text { Bogdan Gorochowskij }\end{array}$ & January 2000 \\
\hline $\begin{array}{l}\text { No. 286: The Quest for Pension Reform: } \\
\text { Poland's Security through Diversity }\end{array}$ & Marek Góra and Michael Rutkowski & January 2000 \\
\hline No. 285: Disorganization and Financial & Dalia Marin and Monika Schnitzer & October 1999 \\
\hline
\end{tabular}




\begin{tabular}{|c|c|c|}
\hline Collapse & & \\
\hline $\begin{array}{l}\text { No. 284: Coordinating Changes in M-form } \\
\text { and U-form Organizations }\end{array}$ & $\begin{array}{l}\text { Yingyi Qian, Gérard Roland and } \\
\text { Chenggang } X u\end{array}$ & May 1999 \\
\hline $\begin{array}{l}\text { No. 283: Why Russian Workers Do Not Move: } \\
\text { Attachment of Workers Through In-Kind } \\
\text { Payments }\end{array}$ & Guido Friebel and Sergei Guriev & October 1999 \\
\hline $\begin{array}{l}\text { No. 282: Lessons From Fiascos in Russian } \\
\text { Corporate Governance }\end{array}$ & Merritt B. Fox and Michael A. Heller & October 1999 \\
\hline $\begin{array}{l}\text { No. 281: Income Distribution and Price } \\
\text { Controls: Targeting a Social Safety Net } \\
\text { During Economic Transition }\end{array}$ & Michael Alexeev and James Leitzel & March 1999 \\
\hline $\begin{array}{l}\text { No. 280: Starting Positions, Reform Speed, } \\
\text { and Economic Outcomes in Transitioning } \\
\text { Economies }\end{array}$ & William Hallagan and Zhang Jun & January 2000 \\
\hline No. 279: The Value of Prominent Directors & Yoshiro Miwa \& J. Mark Ramseyer & October 1999 \\
\hline No. 278: The System Paradigm & János Kornai & April 1998 \\
\hline $\begin{array}{l}\text { No. 277: The Developmental Consequences of } \\
\text { Foreign Direct Investment in the Transition } \\
\text { from Socialism to Capitalism: The } \\
\text { Performance of Foreign Owned Firms in } \\
\text { Hungary }\end{array}$ & Lawrence Peter King & September 1999 \\
\hline $\begin{array}{l}\text { No. 276: Stability and Disorder: An } \\
\text { Evolutionary Analysis of Russia's Virtual } \\
\text { Economy }\end{array}$ & Clifford Gaddy and Barry W. Ickes & November 1999 \\
\hline $\begin{array}{l}\text { No. 275: Limiting Government Predation } \\
\text { Through Anonymous Banking: A Theory with } \\
\text { Evidence from China. }\end{array}$ & $\begin{array}{l}\text { Chong-En Bai, David D. Li, Yingyi Qian } \\
\text { and Yijiang Wang }\end{array}$ & July 1999 \\
\hline *No. 274: Transition with Labour Supply & Tito Boeri & December 1999 \\
\hline $\begin{array}{l}\text { No. 273: Sectoral Restructuring and Labor } \\
\text { Mobility: A Comparative Look at the Czech } \\
\text { Republic }\end{array}$ & Vit Sorm and Katherine Terrell & November 1999 \\
\hline $\begin{array}{l}\text { *No. 272: Published in: Journal of } \\
\text { Comparative Economics "Returns to Human } \\
\text { Capital Under the Communist Wage Grid and } \\
\text { During the Transition to a Market Economy" } \\
\text { Vol. 27, pp. 33-60 1999. }\end{array}$ & $\begin{array}{l}\text { Daniel Munich, Jan Svejnar and Katherine } \\
\text { Terrell }\end{array}$ & October 1999 \\
\hline $\begin{array}{l}\text { No. 271: Barter in Russia: Liquidity Shortage } \\
\text { Versus Lack of Restructuring }\end{array}$ & Sophie Brana and Mathilde Maurel & June 1999 \\
\hline $\begin{array}{l}\text { No. 270: Tests for Efficient Financial } \\
\text { Intermediation with Application to China }\end{array}$ & Albert Park and Kaja Sehrt & March 1999 \\
\hline $\begin{array}{l}\text { No. 269a: Russian Privatization and } \\
\text { Corporate Governance: What Went Wrong? }\end{array}$ & $\begin{array}{l}\text { Bernard Black, Reinier Kraakman and } \\
\text { Anna Tarassova }\end{array}$ & May 2000 \\
\hline $\begin{array}{l}\text { No. 269: Russian Privatization and Corporate } \\
\text { Governance: What Went Wrong? }\end{array}$ & $\begin{array}{l}\text { Bernard Black, Reinier Kraakman and } \\
\text { Anna Tarassova }\end{array}$ & September 1999 \\
\hline $\begin{array}{l}\text { No. 268: Are Russians Really Ready for } \\
\text { Capitalism? }\end{array}$ & Susan Linz & September 1999 \\
\hline $\begin{array}{l}\text { No. 267: Do Stock Markets Promote } \\
\text { Economic Growth? }\end{array}$ & $\begin{array}{l}\text { Randall K. Filer, Jan Hanousek and Nauro } \\
\text { Campos }\end{array}$ & September 1999 \\
\hline $\begin{array}{l}\text { No. 266: Objectivity, Proximity and } \\
\text { Adaptability in Corporate Governance }\end{array}$ & Arnoud W.A Boot and Jonathan R. Macey & September 1999 \\
\hline No. 265: When the Future is not What it Used & Nauro F. Campos, Gerard Hughes, Stepan & September 1999 \\
\hline
\end{tabular}




\begin{tabular}{|c|c|c|}
\hline $\begin{array}{l}\text { to Be: Lessons from the Western European } \\
\text { Experience to Forecasting Education and } \\
\text { Training in Transitional Economies }\end{array}$ & Jurajda, and Daniel Munich & \\
\hline $\begin{array}{l}\text { No. 264: The Institutional Foundation of } \\
\text { Foreign-Invested Enterprises (FIEs) in China }\end{array}$ & Yasheng Huang & September 1999 \\
\hline $\begin{array}{l}\text { No. 263: The Changing Corporate } \\
\text { Governance Paradigm: Implications for } \\
\text { Transition and Developing Countries }\end{array}$ & $\begin{array}{l}\text { Erik Berglof and Ernst-Ludwig von } \\
\text { Thadden }\end{array}$ & June 1999 \\
\hline No. 262: Law Enforcement and Transition & Gerard Roland and Thierry Verdier & May 1999 \\
\hline $\begin{array}{l}\text { No. 261: Soft Budget Constraints, Pecuniary } \\
\text { Externality, and the Dual Track System }\end{array}$ & Jiahua Che & June 2000 \\
\hline $\begin{array}{l}\text { No. 260: Missing Market in Labor Quality: } \\
\text { The Role of Quality Markets in Transiton }\end{array}$ & Gary H. Jefferson & July 1999 \\
\hline $\begin{array}{l}\text { No. 259: Do Corporate Global Environmental } \\
\text { Standards in Emerging Markets Create or } \\
\text { Destroy Market Value }\end{array}$ & $\begin{array}{l}\text { Glen Dowell, Stuart Hart and Bernard } \\
\text { Yeung }\end{array}$ & June 1999 \\
\hline $\begin{array}{l}\text { No. 258: Public Training and Outflows from } \\
\text { Unemployment }\end{array}$ & Patrick A. Puhani & June 1999 \\
\hline $\begin{array}{l}\text { No. 257: Ownership Versus Environment: } \\
\text { Why are Public Sector Firms Ineffecient? }\end{array}$ & Ann P. Bartel and Ann E. Harrison & June 1999 \\
\hline $\begin{array}{l}\text { No. 256: Taxation and Evasion in the } \\
\text { Presence of Exortion by Organized Crime }\end{array}$ & $\begin{array}{l}\text { Michael Alexeev, Eckhard Janeba and } \\
\text { Stefan Osborne }\end{array}$ & November 1999 \\
\hline $\begin{array}{l}\text { No. 255: Revisiting Hungary's Bankruptcy } \\
\text { Episode }\end{array}$ & John P. Bonin and Mark E. Schaffer & September 1999 \\
\hline $\begin{array}{l}\text { No. 254: FDI in Emerging Markets: A Home- } \\
\text { Country View }\end{array}$ & Marina v.N Whitman & June 1999 \\
\hline $\begin{array}{l}\text { No. 253: The Asian Financial Crisis: What } \\
\text { Happened, and What is to be Done }\end{array}$ & Jeffrey D. Sachs and Wing Thye Woo & January 1999 \\
\hline $\begin{array}{l}\text { No. 252: Organizational Law as Asset } \\
\text { Partitioning }\end{array}$ & Henry Hansmann and Reinier Kraakman & September 1999 \\
\hline $\begin{array}{l}\text { No. 251: Consumer Behavior Research in } \\
\text { Emerging Consumer Markets: the Case of the } \\
\text { Optimum Stimulation Level in South Africa }\end{array}$ & $\begin{array}{l}\text { Jan-Benedict E. M. Steenkamp and Steven } \\
\text { M. Burgess }\end{array}$ & September 1999 \\
\hline $\begin{array}{l}\text { No. 250: Property Rights Formation and the } \\
\text { Organization of Exchange and Production in } \\
\text { Rural China }\end{array}$ & $\begin{array}{l}\text { Matthew A. Turner, Loren Brandt, and } \\
\text { Scott Rozelle }\end{array}$ & July 1998 \\
\hline $\begin{array}{l}\text { No. 249: Impacts of the Indonesian Economic } \\
\text { Crisis: Price Changes and the Poor }\end{array}$ & $\begin{array}{l}\text { James Levinsohn, Steven Berry, and Jed } \\
\text { Friedman }\end{array}$ & June 1999 \\
\hline $\begin{array}{l}\text { No. 248: Internal Barriers in the Transition of } \\
\text { Enterprises from Central Plan to Market }\end{array}$ & Charalambos Vlachoutsicos & July 1999 \\
\hline $\begin{array}{l}\text { No. 247: Spillovers from Multinationals in } \\
\text { Developing Countries: the Mechanisms at } \\
\text { Work }\end{array}$ & Richard E. Caves & June 1999 \\
\hline $\begin{array}{l}\text { No. 246: Dynamism and Inertia on the } \\
\text { Russian Labour Market: A Model of } \\
\text { Segmentation }\end{array}$ & $\begin{array}{l}\text { Irena Grosfeld, Claudia Senik-Leygonie, } \\
\text { Thierry Verdier, Stanislav Kolenikov and } \\
\text { Elena Paltseva }\end{array}$ & May 1999 \\
\hline $\begin{array}{l}\text { No. 245: Lessons from Bank Privatization in } \\
\text { Central Europe }\end{array}$ & John Bonin and Paul Wachtel & May 1999 \\
\hline $\begin{array}{l}\text { No. 244: Nominal-Real Tradeoffs and the } \\
\text { Effects of Monetary Policy: the Romanian } \\
\text { Experience }\end{array}$ & Christian Popa & December 1998 \\
\hline No. 243: Privatization, Political Risk and & Enrico C. Perotti and Pieter van Oijen & March 1999 \\
\hline
\end{tabular}




\begin{tabular}{|c|c|c|}
\hline $\begin{array}{l}\text { Stock Market Development in Emerging } \\
\text { Economies }\end{array}$ & & \\
\hline $\begin{array}{l}\text { No. 242: Investment Financing in Russian } \\
\text { Financial-Industrial Groups }\end{array}$ & Enrico C. Perotti and Stanislav Gelfer & October 1998 \\
\hline $\begin{array}{l}\text { No. 241: Can governments maintain hard } \\
\text { budget constraints? Bank lending and } \\
\text { financial isolation in Romania }\end{array}$ & $\begin{array}{l}\text { Octavian Carare, Constantijn Claessens, } \\
\text { Enrico C. Perotti }\end{array}$ & January 1999 \\
\hline $\begin{array}{l}\text { No. 240: Democratic Institutions and } \\
\text { Economic Reform: the Polish Case }\end{array}$ & $\begin{array}{l}\text { John E. Jackson, Jacek Klich, and } \\
\text { Krystyna Poznanska }\end{array}$ & April 1998 \\
\hline $\begin{array}{l}\text { No. 239: A Longitudinal Study of IJV } \\
\text { Performance in Eastern Europe }\end{array}$ & Keith D. Brouthers and Gary Bamossy & June 1999 \\
\hline $\begin{array}{l}\text { No. 238: Published in: Journal of Business } \\
\text { Venturing, "Firm Creation and Economic } \\
\text { Transitions" Vol. 14, Iss. 5,6 Sep/Nov 1999, } \\
\text { pp. 427-450. }\end{array}$ & $\begin{array}{l}\text { John E. Jackson, Jacek Klich, Krystyna } \\
\text { Poznanska }\end{array}$ & July 1998 \\
\hline $\begin{array}{l}\text { No. 237: Analysis of Entrepreneurial Attitudes } \\
\text { in Poland }\end{array}$ & $\begin{array}{l}\text { John E. Jackson and Aleksander S. } \\
\text { Marcinkowski }\end{array}$ & March 1997 \\
\hline $\begin{array}{l}\text { No. 236: Investment and Finance in De Novo } \\
\text { Private Firms: Empirical Results from the } \\
\text { Czech Republic, Hungary, and Poland }\end{array}$ & $\begin{array}{l}\text { Andrzej Bratkowski, Irena Grosfeld, Jacek } \\
\text { Rostowski }\end{array}$ & April 1999 \\
\hline $\begin{array}{l}\text { No. 235: Does a Soft Macroeconomic } \\
\text { Environment Induce Restructuring on the } \\
\text { Microeconomic Level during the Transition } \\
\text { Period? Evidence from Investment Behavior } \\
\text { of Czech Enterprises }\end{array}$ & Lubomír Lízal & June 1999 \\
\hline $\begin{array}{l}\text { No. 234: Banking Reform in China: Gradually } \\
\text { Strengthening Pillar or Fragile Reed? }\end{array}$ & John Bonin & June 1999 \\
\hline $\begin{array}{l}\text { No. 233: Theories of Soft Budget Constraints } \\
\text { and the Analysis of Banking Crises }\end{array}$ & Janet Mitchell & March 1999 \\
\hline $\begin{array}{l}\text { No. 232: Unemployment Risk, Precautionary } \\
\text { Savings, and Moonlighting in Russia }\end{array}$ & $\begin{array}{l}\text { Alessandra Guariglia and Byung-Yeon } \\
\text { Kim }\end{array}$ & June 1999 \\
\hline $\begin{array}{l}\text { No. 231: Investing in Turbulent Times: The } \\
\text { Investment Behavior of Polish Firms in the } \\
\text { Transition }\end{array}$ & $\begin{array}{l}\text { Josef C. Brada, Arthur E. King, and Chia- } \\
\text { Ying Ma }\end{array}$ & April 1999 \\
\hline $\begin{array}{l}\text { No. 230: The End of Moderate Inflation in } \\
\text { Three Transition Economies? }\end{array}$ & Josef C. Brada and Ali M. Kutan & April 1999 \\
\hline $\begin{array}{l}\text { No. 229: Back to the Future: The Growth } \\
\text { Prospects of Transition Economies } \\
\text { Reconsidered }\end{array}$ & Nauro F. Campos & April 1999 \\
\hline $\begin{array}{l}\text { No. 228: The Enterprise Isolation Program in } \\
\text { Russia }\end{array}$ & Simeon Djankov & April 1999 \\
\hline $\begin{array}{l}\text { No. 227: Published in: Journal of } \\
\text { Comparative Economics, "Ownership } \\
\text { Concentration and Corporate Performance in } \\
\text { the Czech Republic" 27(3), September 1999, } \\
\text { pp. 498-513. }\end{array}$ & Stijn Claessens and Simeon Djankov & April 1999 \\
\hline $\begin{array}{l}\text { No. 226: Unemployment Benefit Entitlement } \\
\text { and Training Effects in Poland during } \\
\text { Transition }\end{array}$ & Patrick A. Puhani & March 1999 \\
\hline $\begin{array}{l}\text { No. 225: Transition at Whirlpool-Tatramat: } \\
\text { Case Studies }\end{array}$ & Hans Brechbuhl and Sonia Ferencikova & March 1999 \\
\hline No. 224: Measuring Progress in Transition & Wendy Carlin, Saul Estrin, and Mark & March 1999 \\
\hline
\end{tabular}




\begin{tabular}{|c|c|c|}
\hline $\begin{array}{l}\text { and Towards EU Accession: A Comparison of } \\
\text { Manufacturing Firms in Poland, Romania, } \\
\text { and Spain }\end{array}$ & Schaffer & \\
\hline $\begin{array}{l}\text { No. 223: Product Market Competition in } \\
\text { Transition Economies: Increasing Varieties } \\
\text { and Consumer Loyalty }\end{array}$ & Mitsutoshi M. Adachi & March 1999 \\
\hline $\begin{array}{l}\text { No. 222: Opaque Markets and Rapid Growth: } \\
\text { the Superiority of Bank-Centered Financial } \\
\text { Systems for Developing Nations }\end{array}$ & Rodney Wallace & July 1999 \\
\hline $\begin{array}{l}\text { No. 221: Technology Spillovers through } \\
\text { Foreign Direct Investment }\end{array}$ & Yuko Kinoshita & January 1999 \\
\hline $\begin{array}{l}\text { No. 220: Managerial, Expertise and Team } \\
\text { Centered Forms of Organizing: A Cross- } \\
\text { Cultural Exploration of Independence in } \\
\text { Engineering Work }\end{array}$ & Leslie Perlow & January 1999 \\
\hline $\begin{array}{l}\text { No. 219: Household Structure and Labor } \\
\text { Demand in Agriculture: Testing for } \\
\text { Separability in Rural China }\end{array}$ & Audra J. Bowlus and Terry Sicular & January 1999 \\
\hline $\begin{array}{l}\text { No. 218: Competing Strategies of FDI and } \\
\text { Technology Transfer to China: American and } \\
\text { Japanese Firms }\end{array}$ & W. Mark Fruin and Penelope Prime & January 1999 \\
\hline $\begin{array}{l}\text { No. } 217 \text { Published in: Journal of } \\
\text { Comparative Economics, "Returns to } \\
\text { Mobility in the Transition to a Market } \\
\text { Economy" Vol. 27, No. 1, March 1999, pp. 4- }\end{array}$ & Tito Boeri and Christopher J. Flinn & January 1999 \\
\hline $\begin{array}{l}\text { No. } 216 \text { Published in: Journal of } \\
\text { Comparative Economics, “Labor Market } \\
\text { Policies and Unemployment in the Czech } \\
\text { Republic.”Vol. 27, No. 1, March 1999, pp. } \\
\text { 33-60. }\end{array}$ & Katherine Terrell and Vit Sorm & November 1998 \\
\hline $\begin{array}{l}\text { No. } 215 \text { Published in: Journal of } \\
\text { Comparative Economics, "Active Labor } \\
\text { Market Policies in Poland: Human Capital } \\
\text { Enhancement, Stigmatization or Benefit } \\
\text { Churning?" Vol. 27, No. 1, March 1999, pp. } \\
\text { 61- }\end{array}$ & $\begin{array}{l}\text { Jochen Kluve, Hartmut Lehmann, and } \\
\text { Christoph M. Schmidt }\end{array}$ & December 1998 \\
\hline $\begin{array}{l}\text { No. } 214 \text { Published in: Journal of } \\
\text { Comparative Economics, “Does the } \\
\text { Slovenian Public Work Program Increase } \\
\text { Participants' Chances to Find a Job?" Vol. } \\
\text { 27, No.1, March 1999, pp. 113- }\end{array}$ & Milan Vodopivec & December 1998 \\
\hline $\begin{array}{l}\text { No. } 213 \text { Published in: Journal of } \\
\text { Comparative Economics, "Effects of Active } \\
\text { Labor Market Programs on the Transition } \\
\text { Rate from Unemployment into Regular Jobs in } \\
\text { the Slovak Republic." Vol. 27, No. 1, March } \\
\text { 1999, pp. 90- }\end{array}$ & Martina Lubyova and Jan C. van Ours & December 1998 \\
\hline $\begin{array}{l}\text { No. 212: The Marketing System in Bulgarian } \\
\text { Livestock Production - The Present State and } \\
\text { Evolutionary Processes During the Period of } \\
\text { Economic Transition }\end{array}$ & Yordan Staykov, Team Leader & October 1998 \\
\hline $\begin{array}{l}\text { No. 211: Bankruptcy Experience in Hungary } \\
\text { and the Czech Republic }\end{array}$ & Janet Mitchell & October 1998 \\
\hline
\end{tabular}




\begin{tabular}{|c|c|c|}
\hline $\begin{array}{l}\text { No 210: Values, Optimum Stimulation Levels } \\
\text { and Brand Loyalty: New Scales in New } \\
\text { Populations }\end{array}$ & Steven M. Burgess and Mari Harris & September 1998 \\
\hline $\begin{array}{l}\text { No. 209: Inherited Wealth, Corporate Control } \\
\text { and Economic Growth }\end{array}$ & $\begin{array}{l}\text { Randall K. Morck, David A. Stangeland, } \\
\text { and Bernard Yeung }\end{array}$ & September 1998 \\
\hline $\begin{array}{l}\text { No. 208: A Cultural Analysis of Homosocial } \\
\text { Reproduction and Contesting Claims to } \\
\text { Competence in Transitional Firms }\end{array}$ & Michael D. Kennedy & July 1998 \\
\hline $\begin{array}{l}\text { No. 207: From Survival to Success: The } \\
\text { Journey of Corporate Transformation at } \\
\text { Haier. Forthcoming in Teaching the } \\
\text { Dinosaurs to Dance: Organizational Change } \\
\text { in Transition Economies ed. Daniel Denison. } \\
\text { No. 206: Why Do People Work If They Are } \\
\text { Not Paid? An Example from Eastern Europe. } \\
\text { Forthcoming in Teaching the Dinosaurs to } \\
\text { Dance: Organizational Change in Transition } \\
\text { Economies ed. Daniel Denison. }\end{array}$ & Arthur Yeung and Kenneth DeWoskin & May 1998 \\
\hline $\begin{array}{l}\text { No. 205: Firm Ownership and Work } \\
\text { Motivation in Bulgaria and Hungary: An } \\
\text { Empirical Study of the Transition in the Mid- } \\
\text { 1990s. Forthcoming in Teaching the } \\
\text { Dinosaurs to Dance: Organizational Change } \\
\text { in Transition Economies ed. Daniel Denison. }\end{array}$ & $\begin{array}{l}\text { Robert A. Roe, Irina L. Zinovieva, } \\
\text { Elizabeth Dienes, and Laurens A. ten Horn }\end{array}$ & May 1998 \\
\hline $\begin{array}{l}\text { No. 204: Human Resource Management in the } \\
\text { Restructuring of Chinese Joint Ventures. } \\
\text { Forthcoming in Teaching the Dinosaurs to } \\
\text { Dance: Organizational Change in Transition } \\
\text { Economies ed. Daniel Denison. }\end{array}$ & Nandani Lynton & April 1998 \\
\hline $\begin{array}{l}\text { No. 203: Emergent Compensation Strategies } \\
\text { in Post-Socialist Poland: Understanding the } \\
\text { Cognitive Underpinnings of Management } \\
\text { Practices in a Transition Economy. } \\
\text { Forthcoming in Teaching the Dinosaurs to } \\
\text { Dance: Organizational Change in Transition } \\
\text { Economies ed. Daniel Denison. }\end{array}$ & Marc Weinstein & March 1998 \\
\hline $\begin{array}{l}\text { No. 202: Corporate Transformation and } \\
\text { Organizational Learning: The People's } \\
\text { Republic of China. Forthcoming in Teaching } \\
\text { the Dinosaurs to Dance: Organizational } \\
\text { Change in Transition Economies ed. Daniel } \\
\text { Denison. }\end{array}$ & Meinolf Dierkes and Zhang Xinhua & March 1998 \\
\hline $\begin{array}{l}\text { No. 201: Foreign Direct Investment as a } \\
\text { Factor of Change: The Case of Slovakia. } \\
\text { Forthcoming in Teaching the Dinosaurs to } \\
\text { Dance: Organizational Change in Transition } \\
\text { Economies ed. Daniel Denison. }\end{array}$ & Sonia Ferencikova & February 1998 \\
\hline $\begin{array}{l}\text { No. 200: Radical versus Incremental Change: } \\
\text { The Role of Capabilities, Competition, and } \\
\text { Leaders. Forthcoming in Teaching the } \\
\text { Dinosaurs to Dance: Organizational Change } \\
\text { in Transition Economies ed. Daniel Denison. }\end{array}$ & Karen L. Newman & February 1998 \\
\hline No. 199: The Emergence of Market Practices & Douglas Guthrie & February 1998 \\
\hline
\end{tabular}




\begin{tabular}{|c|c|c|}
\hline $\begin{array}{l}\text { in China's Economic Transition: Price Setting } \\
\text { Practices in Shanghai's Industrial Firms. } \\
\text { Forthcoming in Teaching the Dinosaurs to } \\
\text { Dance: Organizational Change in Transition } \\
\text { Economies ed. Daniel Denison. }\end{array}$ & & \\
\hline $\begin{array}{l}\text { No. 198: The Application of Change } \\
\text { Management Methods at Business } \\
\text { Organizations Operating in Hungary: } \\
\text { Challenges in the Business and Cultural } \\
\text { Environment and First Practical Experiences. } \\
\text { Forthcoming in Teaching the Dinosaurs to } \\
\text { Dance: Organizational Change in Transition } \\
\text { Economies ed. Daniel Denison. }\end{array}$ & Dr. János Fehér & January 1998 \\
\hline $\begin{array}{l}\text { No. 197: Organizational Changes in Russian } \\
\text { Industrial Enterprises: Mutation of Decision- } \\
\text { Making Structures and Transformations of } \\
\text { Ownership. Forthcoming in Teaching the } \\
\text { Dinosaurs to Dance: Organizational Change } \\
\text { in Transition Economies ed. Daniel Denison. }\end{array}$ & Igor B. Gurkov & January 1998 \\
\hline $\begin{array}{l}\text { No. 196: Understanding and Managing } \\
\text { Challenges to the Romanian Companies } \\
\text { during Transition. Forthcoming in Teaching } \\
\text { the Dinosaurs to Dance: Organizational } \\
\text { Change in Transition Economies ed. Daniel } \\
\text { Denison. }\end{array}$ & Dan Candea and Rodica M. Candea & January 1998 \\
\hline $\begin{array}{l}\text { No. 195: Insider Lending and Economic } \\
\text { Transition: The Structure, Function, and } \\
\text { Performance Impact of Finance Companies in } \\
\text { Chinese Business Groups. Forthcoming in } \\
\text { Teaching the Dinosaurs to Dance: } \\
\text { Organizational Change in Transition } \\
\text { Economies ed. Daniel Denison. }\end{array}$ & Lisa A. Keister & December 1997 \\
\hline $\begin{array}{l}\text { No. 194: Japanese Investment in Transitional } \\
\text { Economies: Characteristics and Performance. } \\
\text { Forthcoming in Teaching the Dinosaurs to } \\
\text { Dance: Organizational Change in Transition } \\
\text { Economies ed. Daniel Denison. }\end{array}$ & Paul W. Beamish and Andrew Delios & November 1997 \\
\hline $\begin{array}{l}\text { No. 193: Building Successful Companies in } \\
\text { Transition Economies. Forthcoming in } \\
\text { Teaching the Dinosaurs to Dance: } \\
\text { Organizational Change in Transition } \\
\text { Economies ed. Daniel Denison. }\end{array}$ & Dr. Ivan Perlaki & January 1998 \\
\hline $\begin{array}{l}\text { No. 192: Russian Communitariansim: An } \\
\text { Invisible Fist in the Transformation Process of } \\
\text { Russia. Forthcoming in Teaching the } \\
\text { Dinosaurs to Dance: Organizational Change } \\
\text { in Transition Economies ed. Daniel Denison. }\end{array}$ & Charalambos Vlachoutsicos & July 1998 \\
\hline No. 191: Teaching the Dinosaurs to Dance & Michal Cakrt & September 1997 \\
\hline $\begin{array}{l}\text { No. 190: Strategic Restructuring: Making } \\
\text { Capitalism in Post-Communist Eastern } \\
\text { Europe. Forthcoming in Teaching the } \\
\text { Dinosaurs to Dance: Organizational Change } \\
\text { in Transition Economies ed. Daniel Denison. }\end{array}$ & Lawrence P. King & September 1997 \\
\hline
\end{tabular}




\begin{tabular}{|c|c|c|}
\hline $\begin{array}{l}\text { No. 189: Published in: Regional Science and } \\
\text { Urban Economics, "Russia's Internal } \\
\text { Border", } 29 \text { (5), September 1999. }\end{array}$ & Daniel Berkowitz and David N. DeJong & July 1998 \\
\hline $\begin{array}{l}\text { No. 187: Corporate Structure and } \\
\text { Performance in Hungary }\end{array}$ & László Halpern and Gábor Kórsöi & July 1998 \\
\hline $\begin{array}{l}\text { No. 186: Performance of Czech Companies by } \\
\text { Ownership Structure }\end{array}$ & Andrew Weiss and Georgiy Nikitin & June 1998 \\
\hline $\begin{array}{l}\text { No. 185: Firm Performance in Bulgaria and } \\
\text { Estonia: The effects of competitive pressure, } \\
\text { financial pressure and disorganisation }\end{array}$ & Jozef Konings & July 1998 \\
\hline $\begin{array}{l}\text { No. 184: Investment and Wages during the } \\
\text { Transition: Evidence from Slovene Firms }\end{array}$ & Janez Prasnikar and Jan Svejnar & July 1998 \\
\hline $\begin{array}{l}\text { No. 183: Investment Portfolio under Soft } \\
\text { Budget: Implications for Growth, Volatility } \\
\text { and Savings }\end{array}$ & Chongen Bai and Yijiang Wang & \\
\hline $\begin{array}{l}\text { No. 181: Delegation and Delay in Bank } \\
\text { Privatization }\end{array}$ & Loránd Ambrus-Lakatos and Ulrich Hege & July 1998 \\
\hline $\begin{array}{l}\text { No. 180: Financing Mechanisms and } R \& D \\
\text { Investment }\end{array}$ & Haizhou Huang and Chenggang $X u$ & July 1998 \\
\hline $\begin{array}{l}\text { No. 179: Organizational Culture and } \\
\text { Effectiveness: The Case of Foreign Firms in } \\
\text { Russia }\end{array}$ & Carl F. Fey and Daniel R. Denison & January 1999 \\
\hline $\begin{array}{l}\text { No. 178: Output and Unemployment } \\
\text { Dynamics in Transition }\end{array}$ & Vivek H. Dehejia and Douglas W. Dwyer & January 1998 \\
\hline $\begin{array}{l}\text { No. 177: Published in: Economics of } \\
\text { Transition,, "Bureaucracies in the Russian } \\
\text { Voucher Privatization" Vol. 8, No. 1, 2000, } \\
\text { pp. 37-57. }\end{array}$ & Guido Friebel & June 1998 \\
\hline $\begin{array}{l}\text { No. 176: Chronic Moderate Inflation in } \\
\text { Transition: The Tale of Hungary }\end{array}$ & János Vincze & June 1998 \\
\hline $\begin{array}{l}\text { No. 175: Privatisation and Market Structure } \\
\text { in a Transition Economy }\end{array}$ & John Bennett and James Maw & June 1998 \\
\hline $\begin{array}{l}\text { No. 174: Ownership and Managerial } \\
\text { Competition: Employee, Customer, or Outside } \\
\text { Ownership }\end{array}$ & Patrick Bolton and Chenggang $X u$ & June 1998 \\
\hline $\begin{array}{l}\text { No. 173: Intragovernment Procurement of } \\
\text { Local Public Good: A Theory of } \\
\text { Decentralization in Nondemocratic } \\
\text { Government }\end{array}$ & Chong-en Bai, Yu Pan and Yijiang Wang & June 1998 \\
\hline $\begin{array}{l}\text { No. 172: Political Instability and Growth in } \\
\text { Proprietary Economies }\end{array}$ & Jody Overland and Michael Spagat & August 1998 \\
\hline $\begin{array}{l}\text { No. 171: Published in Post-Communist } \\
\text { Economies, "Framework Issues in the } \\
\text { Privatization Strategies of the Czech Republic, } \\
\text { Hungary, and Poland" Vol. 11, no. 1 March } \\
\text { 1999. }\end{array}$ & Morris Bornstein & June 1998 \\
\hline $\begin{array}{l}\text { No. 170: Published in: European Journal of } \\
\text { Political Economy "Privatization, Ownership } \\
\text { Structure and Transparency: How to Measure } \\
\text { a Real Involvement of the State" 15(4), } \\
\text { November 1999, pp. 605-18. }\end{array}$ & Frantisek Turnovec & May 1998 \\
\hline No. 169 Published in: American Economic & John C. Ham, Jan Svejnar, and Katherine & December 199 \\
\hline
\end{tabular}




\begin{tabular}{|c|c|c|}
\hline $\begin{array}{l}\text { Review, "Unemployment and the Social Safety } \\
\text { Net during Transitions to a Market Economy: } \\
\text { Evidence from Czech and Slovak Men." Vol. } \\
\text { 88, No. 5, Dec. 1998, pp. 1117-1142. }\end{array}$ & Terrell & \\
\hline $\begin{array}{l}\text { No. 167: Voucher Privatization with } \\
\text { Investment Funds: An Institutional Analysis }\end{array}$ & David Ellerman & March 1998 \\
\hline $\begin{array}{l}\text { No. 166: Published in: Marketing Issues in } \\
\text { Transitional Economies, "Value Priorities } \\
\text { and Consumer Behavior in a Transitional } \\
\text { Economy: The Case of South Africa" ed. } \\
\text { Rajeev Batra. }\end{array}$ & $\begin{array}{l}\text { Steven M. Burgess and Jan-Benedict E.M. } \\
\text { Steenkamp }\end{array}$ & August 1998 \\
\hline $\begin{array}{l}\text { No. 164: Finance and Investment in } \\
\text { Transition: Czech Enterprises, 1993-1994 }\end{array}$ & Ronald Anderson and Chantal Kegels & September 1997 \\
\hline $\begin{array}{l}\text { No. 163: European Union Trade and } \\
\text { Investment Flows U-Shaping Industrial } \\
\text { Output in Central and Eastern Europe: } \\
\text { Theory and Evidence }\end{array}$ & Alexander Repkine and Patrick $P$. Walsh & April 1998 \\
\hline $\begin{array}{l}\text { No. 162: Skill Acquisition and Private Firm } \\
\text { Creation in Transition Economies }\end{array}$ & Zuzana Brixiova and Wenli $\mathrm{Li}$ & October 1999 \\
\hline No. 161: Corruption in Transition & Susanto Basu and David D. Li & May 1998 \\
\hline $\begin{array}{l}\text { No. 160a: Tenures that Shook the World: } \\
\text { Worker Turnover in Russia, Poland and } \\
\text { Britain }\end{array}$ & $\begin{array}{l}\text { Hartmut Lehmann and Jonathan } \\
\text { Wadsworth }\end{array}$ & November 1999 \\
\hline $\begin{array}{l}\text { No. 160: Tenures that Shook the World: } \\
\text { Worker Turnover in the Russian Federation } \\
\text { and Poland }\end{array}$ & $\begin{array}{l}\text { Hartmut Lehmann and Jonathan } \\
\text { Wadsworth }\end{array}$ & June 1998 \\
\hline $\begin{array}{l}\text { No. 159: Does Market Structure Matter? New } \\
\text { Evidence from Russia }\end{array}$ & Annette N. Brown and J. David Brown & June 1998 \\
\hline $\begin{array}{l}\text { No. 158: Structural Adjustment and Regional } \\
\text { Long Term Unemployment in Poland }\end{array}$ & Hartmut Lehmann and Patrick P. Walsh & June 1997 \\
\hline $\begin{array}{l}\text { No. 157: Baby Boom or Bust? Changing } \\
\text { Fertility in Post-Communist Czech Republic } \\
\text { and Slovakia }\end{array}$ & Robert S. Chase & April 1998 \\
\hline $\begin{array}{l}\text { No. } 156 \text { Published in: Leadership and } \\
\text { Organization Development Journal, } \\
\text { "Leading Radical Change in Transition } \\
\text { Economies." Vol. 19, No. 6, 1998, pp. 309- } \\
324 .\end{array}$ & Karen L. Newman & June 1998 \\
\hline $\begin{array}{l}\text { No. } 155 \text { Published in: Oxford Review of } \\
\text { Economic Policy, "From Theory into } \\
\text { Practice? Restructuring and Dynamism in } \\
\text { Transition Economies." Vol. 13, No. 2, } \\
\text { Summer 1997, pp. 77-105. }\end{array}$ & Wendy Carlin and Michael Landesmann & June 1997 \\
\hline $\begin{array}{l}\text { No. 154: The Model and the Reality: } \\
\text { Assessment of Vietnamese SOE Reform- } \\
\text { Implementation at the Firm Level }\end{array}$ & $\begin{array}{l}\text { Edmund Malesky, Vu Thanh Hung, Vu Thi } \\
\text { Dieu Anh, and Nancy K. Napier }\end{array}$ & July 1998 \\
\hline $\begin{array}{l}\text { No. } 153 \text { Published in: Journal of } \\
\text { Comparative Economics, "Causes of the Soft } \\
\text { Budget Constraint: Evidence on Three } \\
\text { Explanations." Vol. 26, No. 1, March 1998, } \\
\text { pp. 104-116. }\end{array}$ & David D. Li and Minsong Liang & March 1998 \\
\hline No. 152 Published in: Comparative Economic & Susan J. Linz and Gary Krueger & April 1998 \\
\hline
\end{tabular}




\begin{tabular}{|c|c|c|}
\hline $\begin{array}{l}\text { Studies, "Enterprise Restructuring in Russia's } \\
\text { Transition Economy: Formal and Informal } \\
\text { Mechanisms." Vol. 40, No. 2, Summer 1998, } \\
\text { pp. 5-52. }\end{array}$ & & \\
\hline $\begin{array}{l}\text { No. 151: Labor Productivity in Transition: A } \\
\text { Regional Analysis of Russian Industry }\end{array}$ & Susan J. Linz & May 1998 \\
\hline $\begin{array}{l}\text { No. 150: Tax Avoidance and the Allocation of } \\
\text { Credit. Forthcoming in Financial Systems in } \\
\text { Transition: The Design of Financial Systems } \\
\text { in Central Europe eds. Anna Meyendorff and } \\
\text { Anjan Thakor. }\end{array}$ & Anna Meyendorff & June 1998 \\
\hline $\begin{array}{l}\text { No. 149: Commitment, Versatility and } \\
\text { Balance: Determinants of Work Time } \\
\text { Standards and Norms in a Multi-Country } \\
\text { Study of Software Engineers }\end{array}$ & Leslie Perlow and Ron Fortgang & April 1998 \\
\hline $\begin{array}{l}\text { No. 148: Changes in Poland's Transfer } \\
\text { Payments in the 1990s: the Fate of } \\
\text { Pensioners }\end{array}$ & Bozena Leven & June 1998 \\
\hline $\begin{array}{l}\text { No. 147: Environmental Protection and } \\
\text { Economic Development: The Case of the } \\
\text { Huaihe River Basin Cleanup Plan }\end{array}$ & $\begin{array}{l}\text { Robert Letovsky, Reze Ramazani, and } \\
\text { Debra Murphy }\end{array}$ & June 1998 \\
\hline $\begin{array}{l}\text { No. 146: Chief Executive Compensation } \\
\text { During Early Transition: Further Evidence } \\
\text { from Bulgaria }\end{array}$ & $\begin{array}{l}\text { Derek C. Jones, Takao Kato, and Jeffrey } \\
\text { Miller }\end{array}$ & June 1998 \\
\hline $\begin{array}{l}\text { No. } 145 \text { Published in: Economics of } \\
\text { Transition, “Women's Unemployment During } \\
\text { the Transition: Evidence from Czech and } \\
\text { Slovak Micro Data," Vol. 7, No. 1, May 1999, } \\
\text { pp. 47-78. }\end{array}$ & $\begin{array}{l}\text { John Ham, Jan Svejnar, and Katherine } \\
\text { Terrell }\end{array}$ & May 1998 \\
\hline No. 144: Investment and Wages in Slovenia & Janez Prasnikar & May 1998 \\
\hline $\begin{array}{l}\text { No. } 143 \text { Published in: Review of Financial } \\
\text { Studies, "Optimal Bankruptcy Laws Across } \\
\text { Different Economic Systems," 12(2), Summer } \\
1999, \text { pgs. 347-77. }\end{array}$ & Elazar Berkovitch and Ronen Israel & March 1998 \\
\hline $\begin{array}{l}\text { No. 142: Industrial Policy and Poverty in } \\
\text { Transition Economies: Two Steps Forward or } \\
\text { One Step Back? }\end{array}$ & Susan J. Linz & March 1998 \\
\hline $\begin{array}{l}\text { No. 141: Collective Ownership and } \\
\text { Privatization of China's Village Enterprises }\end{array}$ & Suwen Pan and Albert Park & April 1998 \\
\hline $\begin{array}{l}\text { No. 140: A Comparative Look at Labor } \\
\text { Mobility in the Czech Republic: Where have } \\
\text { all the Workers Gone? }\end{array}$ & Vit Sorm and Katherine Terrell & April 1999 \\
\hline $\begin{array}{l}\text { No. 139: The Failure of the Government-Led } \\
\text { Program of Corporate Reorganization in } \\
\text { Romania }\end{array}$ & Simeon Djankov and Kosali Ilayperuma & September 1997 \\
\hline $\begin{array}{l}\text { No. 138: Ownership and Employment in } \\
\text { Russian Industry: 1992-1995 }\end{array}$ & Susan J. Linz & March 1998 \\
\hline $\begin{array}{l}\text { No. } 137 \text { Published in: Journal of Political } \\
\text { Economy, "Reform Without Losers: An } \\
\text { Interpretation of China's Dual-Track } \\
\text { Approach to Transition," Feb. 2000; Vol. 108, } \\
\text { Iss.1; pg. } 120\end{array}$ & $\begin{array}{l}\text { Lawrence J. Lau, Yingyi Qian, and Gerard } \\
\text { Roland }\end{array}$ & November 1997 \\
\hline
\end{tabular}




\begin{tabular}{|c|c|c|}
\hline $\begin{array}{l}\text { No. } 136 \text { Published in: European Economic } \\
\text { Review, "The Political Economy of Mass } \\
\text { Privatization and the Risk of Expropriation," } \\
44(2), \text { February 2000, pgs. } 393-421\end{array}$ & Klaus M. Schmidt & March 1998 \\
\hline $\begin{array}{l}\text { No. 135: Radical Organizational Change: The } \\
\text { Role of Starting Conditions, Competition, and } \\
\text { Leaders }\end{array}$ & Karen L. Newman & January 1998 \\
\hline $\begin{array}{l}\text { No. 134: To Restructure or Not to } \\
\text { Restructure: Informal Activities and } \\
\text { Enterprise Behavior in Transition } \\
\text { No. 133: Management 101: Behavior of Firms } \\
\text { in Transition Economies }\end{array}$ & $\begin{array}{l}\text { Clifford Gaddy and Barry W. Ickes } \\
\text { Josef C. Brada }\end{array}$ & $\begin{array}{l}\text { May } 1998 \\
\text { March } 1998\end{array}$ \\
\hline $\begin{array}{l}\text { No. } 132 \text { Published in: Quarterly Journal of } \\
\text { Economics, "Interfirm Relationships and } \\
\text { Informal Credit in Vietnam," 114(4), Nov. } \\
\text { 1999, pgs. } 1285-1320\end{array}$ & John McMillan and Christopher Woodruff & February 1998 \\
\hline $\begin{array}{l}\text { No. } 131 \text { Published in: Comparative Economic } \\
\text { Studies, “Will Restructuring Hungarian } \\
\text { Companies Innovate? An Investigation Based } \\
\text { on Joseph Berliner's Analysis of Innovation in } \\
\text { Soviet Industry.” Vol. 40, No. 2, Summer } \\
\text { 1998, pp. 53-74. }\end{array}$ & John B. Bonin and Istvan Abel & March 1998 \\
\hline $\begin{array}{l}\text { No. 130: Published in The American } \\
\text { Economic Review, "Changing Incentives of } \\
\text { the Chinese Bureaucracy." May, } 1998 .\end{array}$ & David D. Li & January 1998 \\
\hline $\begin{array}{l}\text { No. 129: Restructuring Investment in } \\
\text { Transition: A Model of the Enterprise } \\
\text { Decision }\end{array}$ & Richard E. Ericson & January 1998 \\
\hline $\begin{array}{l}\text { No. } 128 \text { Published in: Comparative Economic } \\
\text { Studies, “Job Rights in Russian Firms: } \\
\text { Endangered or Extinct Institutions?” Vol. 40, } \\
\text { No. 4, Winter 1998, pp. 1-32. }\end{array}$ & Susan J. Linz & January 1998 \\
\hline $\begin{array}{l}\text { No. 127: Accounting for Growth in Post- } \\
\text { Soviet Russia }\end{array}$ & Daniel Berkowitz and David N. DeJong & January 1998 \\
\hline $\begin{array}{l}\text { No. } 126 \text { Published in: Economics of } \\
\text { Transition, "From Federalism, Chinese Style, } \\
\text { to Privatization Chinese Style," 7(1), 1999, } \\
\text { pgs. 103-31 }\end{array}$ & $\begin{array}{l}\text { Yuanzheng Cao, Yingyi Qian, and Barry R. } \\
\text { Weingast }\end{array}$ & December 1997 \\
\hline $\begin{array}{l}\text { No. 125: Market Discipline in Conglomerate } \\
\text { Banks: Is an Internal Allocation of Cost of } \\
\text { Capital Necessary as Incentive Device? } \\
\text { Forthcoming in Financial Systems in } \\
\text { Transition: The Design of Financial Systems } \\
\text { in Central Europe eds. Anna Meyendorff and } \\
\text { Anjan Thakor. }\end{array}$ & Arnoud W. A. Boot and Anjolein Schmeits & November 1997 \\
\hline $\begin{array}{l}\text { No. 124: Financial Discipline in the } \\
\text { Enterprise Sector in Transition Countries: } \\
\text { How Does China Compare? }\end{array}$ & Shumei Gao and Mark E. Schaffer & February 1998 \\
\hline $\begin{array}{l}\text { No. 123: Considerations of an Emerging } \\
\text { Marketplace: Managers' Perceptions in the } \\
\text { Southern African Economic Community }\end{array}$ & Brent Chrite and David Hudson & February 1998 \\
\hline $\begin{array}{l}\text { No. 122: A Model of the Informal Economy in } \\
\text { Transition Economies }\end{array}$ & $\begin{array}{l}\text { Simon Commander and Andrei } \\
\text { Tolstopiatenko }\end{array}$ & November 1997 \\
\hline
\end{tabular}




\begin{tabular}{|c|c|c|}
\hline $\begin{array}{l}\text { No. 121: Local Labour Market Dynamics in } \\
\text { the Czech and Slovak Republics }\end{array}$ & Peter Huber and Andreas Worgotter & November 1997 \\
\hline $\begin{array}{l}\text { No. 121: Local Labour Market Dynamics in } \\
\text { the Czech and Slovak Republics }\end{array}$ & Peter Huber and Andreas Worgotter & November 1997 \\
\hline $\begin{array}{l}\text { No. 119: Institutional Upheaval and Company } \\
\text { Transformation in Emerging Market } \\
\text { Economies }\end{array}$ & Karen L. Newman & March 1998 \\
\hline $\begin{array}{l}\text { No. 118: Industrial Decline and Labor } \\
\text { Reallocation in Romania }\end{array}$ & John S. Earle & October 1997 \\
\hline $\begin{array}{l}\text { No. 117: Notes for an Essay on the Soft } \\
\text { Budget Constraint }\end{array}$ & Lorand Ambrus-Lakatos & January 1997 \\
\hline $\begin{array}{l}\text { No. 116: Labor Demand During Transition in } \\
\text { Hungary }\end{array}$ & Gabor Korosi & October 1997 \\
\hline $\begin{array}{l}\text { No. 115: Enterprise Performance and } \\
\text { Managers' Profiles }\end{array}$ & Simeon Djankov and Stijn Claessens & December 1997 \\
\hline $\begin{array}{l}\text { No. } 114 \text { b Employment and Wages in } \\
\text { Enterprises under Communism and in } \\
\text { Transition: Evidence From Central Europe } \\
\text { and Russia }\end{array}$ & Swati Basu, Saul Estrin, and Jan Svejnar & April 2000 \\
\hline $\begin{array}{l}\text { No. 114: Employment and Wage Behavior of } \\
\text { Enterprises in Transitional Economies }\end{array}$ & Swati Basu, Saul Estrin, and Jan Svejnar & October 1997 \\
\hline $\begin{array}{l}\text { No. 113: Preliminary Evidence on Active } \\
\text { Labor Programs' Impact in Hungary and } \\
\text { Poland }\end{array}$ & Christopher J. O'Leary & October 1997 \\
\hline $\begin{array}{l}\text { No. 111: Unemployment Benefits and } \\
\text { Incentives in Hungary: New Evidence }\end{array}$ & Joachim Wolff & October 1997 \\
\hline $\begin{array}{l}\text { No. 110: Published in: Empirical Economics, } \\
\text { "Long-Term Unemployment, Unemployment } \\
\text { Benefits and Social Assistance: The Polish } \\
\text { Experience" Empirical-Economics; 23(1-2), } \\
\text { 1998, pages 55-85. }\end{array}$ & Marek Gora and Christoph M. Schmidt & April 1997 \\
\hline $\begin{array}{l}\text { No. } 109 \text { Published in: Industrial and Labor } \\
\text { Relations Review, "Markets for Communist } \\
\text { Human Capital: Returns to Education and } \\
\text { Experience in Post-Communist Czech } \\
\text { Republic and Slovakia." Vol. 51, No. 3, April } \\
\text { 1998, pp. 401-423. }\end{array}$ & Robert S. Chase & October 1997 \\
\hline $\begin{array}{l}\text { No. 107: The Worker-Firm Matching in the } \\
\text { Transition: (Why) Are the Czechs More } \\
\text { Successful Than Others? }\end{array}$ & $\begin{array}{l}\text { Daniel Münich, Jan Svejnar, and } \\
\text { Katherine Terrell }\end{array}$ & October 1997 \\
\hline $\begin{array}{l}\text { No. } 106 \text { Published in: Journal of } \\
\text { Comparative Economics, “Job Creation, Job } \\
\text { Destruction and Growth of Newly Established, } \\
\text { Privatized and State-Owned Enterprises in } \\
\text { Transition Economies: Survey Evidence from } \\
\text { Bulgaria, Hungary, and Romania," Vol. 26, } \\
\text { No.3, September 1998, pp. 429-445. } \\
\end{array}$ & Valentijn Bilsen and Jozef Konings & September 1998 \\
\hline $\begin{array}{l}\text { No. 105: Getting Behind the East-West } \\
\text { [German] Wage Differential: Theory and } \\
\text { Evidence }\end{array}$ & Michael Burda and Christoph Schmidt & May 1997 \\
\hline $\begin{array}{l}\text { No. 104: The Birth of the "Wage Curve" in } \\
\text { Hungary, 1989-95 }\end{array}$ & Gabor Kertesi and Janos Kollo & October 1997 \\
\hline
\end{tabular}




\begin{tabular}{|c|c|c|}
\hline $\begin{array}{l}\text { No. 103: Published in: Journal of } \\
\text { Comparative Economics, "Grime and } \\
\text { Punishment: Job Insecurity and Wage Arrears } \\
\text { in the Russian Federation" 27, 595-617 } \\
\text { (1999). }\end{array}$ & $\begin{array}{l}\text { Hartmut Lehmann, Jonathan Wadsworth, } \\
\text { and Alessandro Acquisti }\end{array}$ & October 1997 \\
\hline No. 102: Social Networks in Transition & $\begin{array}{l}\text { Lorena Barberia, Simon Johnson, and } \\
\text { Daniel Kaufmann }\end{array}$ & October 1997 \\
\hline $\begin{array}{l}\text { No. 101: Depreciation and Russian Corporate } \\
\text { Finance: A Pragmatic Approach to Surviving } \\
\text { the Transition }\end{array}$ & Susan J. Linz & November 1997 \\
\hline No. 100: Romanian Financial System Reform & Anna Meyendorff and Anjan V. Thakor & November 1997 \\
\hline $\begin{array}{l}\text { No. 99: Proceedings of the Conference on } \\
\text { Strategic Alliances in Transitional Economies, } \\
\text { held May 20,1997 at the Davidson Institute }\end{array}$ & Edited by Cynthia Koch & May 1997 \\
\hline $\begin{array}{l}\text { No. 98: Institutions, Strain and the } \\
\text { Underground Economy }\end{array}$ & Daniel Daianu and Lucian Albu & November 1997 \\
\hline $\begin{array}{l}\text { No. 97: Structure and Strain in Explaining } \\
\text { Inter-Enterprise Arrears } \\
\text { No. 96: Resource Misallocation and Strain: } \\
\text { Explaining Shocks in Post-Command } \\
\text { Economies }\end{array}$ & $\begin{array}{l}\text { Daniel Daianu } \\
\text { Daniel Daianu }\end{array}$ & $\begin{array}{l}\text { November } 1997 \\
\text { November } 1997\end{array}$ \\
\hline $\begin{array}{l}\text { No. 95: Published in: Finance-a-Uver, } \\
\text { "Czech Money Market: Emerging Links } \\
\text { Among Interest Rates." 48(2) } 1998 \text { pp. } 99 \text { - } \\
\text { 109. }\end{array}$ & Jan Hanousek and Evzen Kocenda & November 1997 \\
\hline $\begin{array}{l}\text { No. 94: Pre-Reform Industry and the } \\
\text { State Monopsony in China }\end{array}$ & Xiao-Yuan Dong and Louis Putterman & October 1997 \\
\hline $\begin{array}{l}\text { No. 93: China's State-Owned Enterprises } \\
\text { In the First Reform Decade: } \\
\text { An Analysis of a Declining Monopsony }\end{array}$ & Xiao-Yuan Dong and Louis Putterman & October 1997 \\
\hline $\begin{array}{l}\text { No. 92: Expatriate Management in the Czech } \\
\text { Republic }\end{array}$ & Richard B. Peterson & September 1997 \\
\hline $\begin{array}{l}\text { No. 91: China and the Idea of Economic } \\
\text { Reform }\end{array}$ & Thomas G. Rawski & April 1997 \\
\hline $\begin{array}{l}\text { No. } 90 \text { Published in: China Economic } \\
\text { Review, “China's State Enterprise Reform: An } \\
\text { Overseas Perspective." Vol. 8, Spring 1997, } \\
\text { pp. } 89-98 .\end{array}$ & Thomas G. Rawski & July 1997 \\
\hline $\begin{array}{l}\text { No. 89: The Economic Determinants of } \\
\text { Internal Migration Flows in Russia During } \\
\text { Transition }\end{array}$ & Annette N. Brown & July 1997 \\
\hline $\begin{array}{l}\text { No. 88: Gender Wage Gaps in China's Labor } \\
\text { Market: Size, Structure, Trends }\end{array}$ & $\begin{array}{l}\text { Margaret Maurer-Fazio, Thomas G. } \\
\text { Rawski, and Wei Zhang }\end{array}$ & July 1997 \\
\hline $\begin{array}{l}\text { No. 87: Privatisation in Central and Eastern } \\
\text { Europe }\end{array}$ & Saul Estrin & June 1997 \\
\hline $\begin{array}{l}\text { No. 86: Published in : Economics of } \\
\text { Transition, "The Effect of Privatization on } \\
\text { Wealth Distribution in Russia." v. 7, no. 2, } \\
\text { 1999, pp. 449-65 }\end{array}$ & Michael Alexeev & February 1998 \\
\hline $\begin{array}{l}\text { No. 85: Was Privatization in Eastern Germany } \\
\text { a Special Case? Some Lessons from the } \\
\text { Treuhand }\end{array}$ & Uwe Siegmund & September 1997 \\
\hline
\end{tabular}




\begin{tabular}{|c|c|c|}
\hline No. 84: Start-ups and Transition & Daniel M. Berkowitz and David J. Cooper & September 1997 \\
\hline $\begin{array}{l}\text { No. 83: Which Enterprises (Believe They) } \\
\text { Have Soft Budgets after Mass Privatization? } \\
\text { Evidence from Mongolia }\end{array}$ & $\begin{array}{l}\text { James Anderson, Georges Korsun, and } \\
\text { Peter Murrell }\end{array}$ & October 1997 \\
\hline $\begin{array}{l}\text { No. 82: Published in: European Economic } \\
\text { Review, "Unemployment Dynamics and the } \\
\text { Restructuring of the Slovak Unemployment } \\
\text { Benefit System." April, } 1997 .\end{array}$ & Martina Lubyova and Jan C. van Ours & June 1997 \\
\hline $\begin{array}{l}\text { No. 81: Determinants of Unemployment } \\
\text { Duration in Russia }\end{array}$ & Mark C. Foley & August 1997 \\
\hline $\begin{array}{l}\text { No. 80: The Many Faces of Information } \\
\text { Disclosure }\end{array}$ & Arnoud W.A. Boot and Anjan V. Thakor & October 1997 \\
\hline $\begin{array}{l}\text { No. 79: Published in: Journal of Finance, } \\
\text { "Foreign Speculators and Emerging Equity } \\
\text { Markets."v.22, iss. 2, 2000, pp. 565-613 }\end{array}$ & Geert Bekaert and Campbell R. Harvey & August 1997 \\
\hline $\begin{array}{l}\text { No. 78: The Relationship Between Economic } \\
\text { Factors and Equity Markets in Central Europe }\end{array}$ & Jan Hanousek and Randall K. Filer & June 1997 \\
\hline $\begin{array}{l}\text { No. } 77 \text { Published in: Economics of } \\
\text { Transition, "A Gini Decomposition Analysis } \\
\text { of Inequality in the Czech and Slovak } \\
\text { Republics During the Transition," Vol. 6, } \\
\text { No.1, May 1998, pp. 23-46. }\end{array}$ & Thesia I. Garner and Katherine Terrell & May 1998 \\
\hline $\begin{array}{l}\text { No. 76: Chinese Enterprise Reform as a } \\
\text { Market Process }\end{array}$ & Gary H. Jefferson and Thomas G. Rawski & June 1997 \\
\hline $\begin{array}{l}\text { No. } 75 b: \text { Test of Permanent Income } \\
\text { Hypothesis on Czech Voucher Privatization }\end{array}$ & Jan Hanousek and Zdenek Tima & October 1997 \\
\hline $\begin{array}{l}\text { No. 74: Determinants of Performance of } \\
\text { Manufacturing Firms in Seven European } \\
\text { Transition Economies }\end{array}$ & $\begin{array}{l}\text { Stijn Claessens, Simeon Djankov, and } \\
\text { Gerhard Pohl }\end{array}$ & February 1997 \\
\hline $\begin{array}{l}\text { No. } 73 \text { Published in: Economics of } \\
\text { Transition, "The Restructuring of Large } \\
\text { Firms in Slovak Republic." Vol. 6, No. 1, May } \\
\text { 1998, pp. 67-85 }\end{array}$ & Simeon Djankov and Gerhard Pohl & May 1998 \\
\hline $\begin{array}{l}\text { No. 72: Law, Relationships, and Private } \\
\text { Enforcement: Transactional Strategies of } \\
\text { Russian Enterprises }\end{array}$ & $\begin{array}{l}\text { Kathryn Hendley, Peter Murrell, and } \\
\text { Randi Ryterman }\end{array}$ & November 1998 \\
\hline $\begin{array}{l}\text { No. 71: Giving Credit Where Credit Is Due: } \\
\text { The Changing Role of Rural Financial } \\
\text { Institutions in China }\end{array}$ & Albert Park, Loren Brandt, and John Giles & March 1997 \\
\hline $\begin{array}{l}\text { No. 70: Privatization Versus Competition: } \\
\text { Changing Enterprise Behavior in Russia }\end{array}$ & John S. Earle and Saul Estrin & Spring 1997 \\
\hline $\begin{array}{l}\text { No. 69: Russian Managers under Storm: } \\
\text { Explicit Reality and Implicit Leadership } \\
\text { Theories (A Pilot Exploration) }\end{array}$ & Igor Gurkov & October 1998 \\
\hline $\begin{array}{l}\text { No. 68: The Political Economy of Central- } \\
\text { Local Relations in China: Inflation and } \\
\text { Investment Controls During the Reform Era }\end{array}$ & Yasheng Huang & Spring 1997 \\
\hline $\begin{array}{l}\text { No. 67: Between Two Coordination Failures: } \\
\text { Automotive Industrial Policy in China with a } \\
\text { Comparison to Korea }\end{array}$ & Yasheng Huang & Spring 1997 \\
\hline $\begin{array}{l}\text { No. } 66 \text { Published in: Post-Soviet Geography } \\
\text { and Economics, "Red Executives in Russia's }\end{array}$ & Susan J. Linz & January 1997 \\
\hline
\end{tabular}




\begin{tabular}{|c|c|c|}
\hline $\begin{array}{l}\text { Transition Economy." Vol. 27, No. 10, } \\
\text { November 1996, pp. 633-651. }\end{array}$ & & \\
\hline $\begin{array}{l}\text { No. } 65 \text { Published in: Industrial and } \\
\text { Corporate Change, "On the Sequencing of } \\
\text { Privatization in Transition Economies." Vol. } \\
7, \text { No. 1, 1998. }\end{array}$ & Gautam Ahuja and Sumit K. Majumdar & April 1997 \\
\hline $\begin{array}{l}\text { No. 64: Published in: Journal of Law and } \\
\text { Economics, "Foreign Ownership and } \\
\text { Profitability: Property Rights, Control and the } \\
\text { Performance of Firms in Indian Industry" } \\
\text { 42(1), April 1999, pp. 209-38. }\end{array}$ & $\begin{array}{l}\text { Pradeep K. Chhibber and Sumit K. } \\
\text { Majumdar }\end{array}$ & April 1997 \\
\hline $\begin{array}{l}\text { No. 63: How Taxing Is Corruption on } \\
\text { International Investors? }\end{array}$ & Shang-Jin Wei & February 1997 \\
\hline $\begin{array}{l}\text { No. 62: What Can We Learn from the } \\
\text { Experience of Transitional Economies with } \\
\text { Labour Market Policies? } \\
\text { No. 61: Published in: Accounting } \\
\text { Organizations and Society, "Economic } \\
\text { Transition, Strategy and the Evolution of } \\
\text { Management Accounting Practices: The Case } \\
\text { of India" 24(5,6), Jul/Aug 1999, pp. 379-412. }\end{array}$ & $\begin{array}{l}\text { Tito Boeri } \\
\text { Shannon W. Anderson and William N. } \\
\text { Lanen }\end{array}$ & 1997 \\
\hline $\begin{array}{l}\text { No. 60a: Enterprise Investment During the } \\
\text { Transition: Evidence from Czech Panel Data }\end{array}$ & Lubomír Lizal and Jan Svejnar & December 1997 \\
\hline $\begin{array}{l}\text { No. 59: Published in: Journal of Law, } \\
\text { Economics, and Organization, "Institutional } \\
\text { Environment, Community Government, and } \\
\text { Corporate Governance: Understanding } \\
\text { China's Township-Village Enterprises." } \\
\text { 14(1), April 1998, pages 1-23 }\end{array}$ & Jiahua Che and Yingyi Qian & April 1997 \\
\hline $\begin{array}{l}\text { No. 58: From the Grabbing Hand to the } \\
\text { Helping Hand }\end{array}$ & Jiahua Che & June 2000 \\
\hline $\begin{array}{l}\text { No. 57: Published in: Brookings Papers on } \\
\text { Economic Activity, "The Unofficial Economy } \\
\text { in Transition." 1: 1998. }\end{array}$ & $\begin{array}{l}\text { Simon Johnson, Daniel Kaufmann, and } \\
\text { Andrei Schleifer }\end{array}$ & June 1997 \\
\hline $\begin{array}{l}\text { No. 56: Taxes and Government Incentives: } \\
\text { Eastern Europe vs. China }\end{array}$ & Roger H. Gordon and David D. Li & April 1997 \\
\hline No. 55: Corruption and Reform & Susanto Basu and David Li & June 1996 \\
\hline $\begin{array}{l}\text { No. 54: Decentralization and the } \\
\text { Macroeconomic Consequences of } \\
\text { Commitment to State-Owned Firms }\end{array}$ & Loren Brandt and Xiaodong Zhu & June 1997 \\
\hline $\begin{array}{l}\text { No. 53: Published in: The International } \\
\text { Journal of Industrial Organization, } \\
\text { "Competitive Shocks and Industrial Structure: } \\
\text { The Case of Polish Manufacturing." August, } \\
\text { 1999. . }\end{array}$ & Pankaj Ghemawat and Robert E. Kennedy & May 1997 \\
\hline $\begin{array}{l}\text { No. 52: Published in: The Quarterly Journal } \\
\text { of Economics, "Insecure Property Rights and } \\
\text { Government Ownership of Firms." May, } \\
\text { 1998. }\end{array}$ & Jiahua Che and Yingyi Qian & May 1997 \\
\hline $\begin{array}{l}\text { No. 51: Incentives, Scale Economies, and } \\
\text { Organizational Form }\end{array}$ & $\begin{array}{l}\text { Eric Maskin, Yingyi Qian, and Chenggang } \\
\mathrm{Xu}\end{array}$ & May 1997 \\
\hline No. 50: Published in: Post-Soviet-Affairs, & Barry W. Ickes, Peter Murrell, and Randi & March 1997 \\
\hline
\end{tabular}




\begin{tabular}{|c|c|c|}
\hline $\begin{array}{l}\text { "End of the Tunnel? The Effects of Financial } \\
\text { Stabilization in Russia" April-June 1997, } \\
\text { pages 105-33 }\end{array}$ & Ryterman & \\
\hline $\begin{array}{l}\text { No. 49: The Evolution of Bank Credit Quality } \\
\text { in Transition: Theory and Evidence from } \\
\text { Romania }\end{array}$ & Enrico C. Perotti and Octavian Carare & October 1996 \\
\hline $\begin{array}{l}\text { No. 48: Where Do the Leaders Trade? } \\
\text { Information Revelation and Interactions } \\
\text { Between the Segments of Czech Capital } \\
\text { Markets }\end{array}$ & Jan Hanousek and Libor Nemecek & May 1997 \\
\hline $\begin{array}{l}\text { No. 47: Firms' Heterogeneity in Transition: } \\
\text { Evidence from a Polish Panel Data Set }\end{array}$ & Irena Grosfeld and Jean-François Nivet & May 1997 \\
\hline $\begin{array}{l}\text { No. 46: Strategic Creditor Passivity, } \\
\text { Regulation, and Bank Bailouts }\end{array}$ & Janet Mitchell & May 1997 \\
\hline $\begin{array}{l}\text { No. } 45 \text { a: Decentralization in Transition } \\
\text { Economies: A Tragedy of the Commons? }\end{array}$ & Daniel M. Berkowitz and Wei Li & September 1997 \\
\hline $\begin{array}{l}\text { No. 44a: The Information Content of Stock } \\
\text { Markets: Why do Emerging Markets have } \\
\text { Synchronous Stock Price Movements? } \\
\text { (forthcoming in the Journal of Financial } \\
\text { Economics). } \\
\text { No. 43: Agency in Project Screening and } \\
\text { Termination Decisions: Why Is Good Money } \\
\text { Thrown After Bad? }\end{array}$ & $\begin{array}{l}\text { Randall Morck, Bernard Yeung, and } \\
\text { Wayne Yu } \\
\text { Chong-en Bai and Yijiang Wang }\end{array}$ & May 1997 \\
\hline $\begin{array}{l}\text { No. 42: Published in: Economics of } \\
\text { Transition, "Channels of Redistribution: } \\
\text { Inequality and Poverty in the Russian } \\
\text { Transition." Vol. } 7 \text { (2) } 1999 .\end{array}$ & $\begin{array}{l}\text { Simon Commander, Andrei } \\
\text { Tolstopiatenko, and Ruslan Yemtsov }\end{array}$ & May 1997 \\
\hline $\begin{array}{l}\text { No. 41: Published in: Economics of } \\
\text { Transition, "Labour Market Characteristics } \\
\text { and Profitability: Econometric Analysis of } \\
\text { Hungarian Exporting Firms, 1986-1995" } \\
\text { 6(1), May 1998, pages 145-62 }\end{array}$ & László Halpern and Gabor Korosi & May 1997 \\
\hline $\begin{array}{l}\text { No. 40: Published in: the Harvard Law } \\
\text { Review, "The Tragedy of the Anticommons: } \\
\text { Property in the Transition from Marx to } \\
\text { Markets." January } 1998 .\end{array}$ & Michael Heller & February 1997 \\
\hline $\begin{array}{l}\text { No. 39: Privatization and Managerial } \\
\text { Efficiency }\end{array}$ & Olivier Debande and Guido Friebel & May 1997 \\
\hline $\begin{array}{l}\text { No. } 38 \text { Published in: The Quarterly Journal } \\
\text { of Economics, "Disorganization." Vol. 112, } \\
\text { No. 4, November 1997, pp. 1091-1126. }\end{array}$ & Olivier Blanchard and Michael Kremer & January 1997 \\
\hline $\begin{array}{l}\text { No. 37: Published in: Economics of } \\
\text { Transition, "Transition and the Output Fall." } \\
7(1), 1999, \text { pages 1-28. }\end{array}$ & Gérard Roland and Thierry Verdier & March 1997 \\
\hline $\begin{array}{l}\text { No. 36: Restructuring an Industry During } \\
\text { Transition: A Two-Period Model }\end{array}$ & Richard Ericson & September 1996 \\
\hline $\begin{array}{l}\text { No. 34: The East-West Joint Venture: } B C \\
\text { Torsion Case Study }\end{array}$ & Sonia Ferencikova and Vern Terpstra & December 1998 \\
\hline $\begin{array}{l}\text { No. } 33 \text { Published in: Journal of Comparative } \\
\text { Economics, "Quantifying Price Liberalization } \\
\text { in Russia." Vol. 26, No. 4, December 1998, }\end{array}$ & $\begin{array}{l}\text { Daniel Berkowitz, David DeJong, and } \\
\text { Steven Husted }\end{array}$ & December 1998 \\
\hline
\end{tabular}




\begin{tabular}{|c|c|c|}
\hline pp. 735-737. & & \\
\hline $\begin{array}{l}\text { No. 32: What Can North Korea Learn from } \\
\text { China's Market Reforms? }\end{array}$ & John McMillan & September 1996 \\
\hline $\begin{array}{l}\text { No. 31: Published in : China-Economic- } \\
\text { Review, "Towards a Model of China as a } \\
\text { Partially Reformed Developing Economy } \\
\text { Under a Semifederalist Government.", 9(1), } \\
\text { Spring 1998, pages 1-23. }\end{array}$ & Yijiang Wang and Chun Chang & March 1997 \\
\hline $\begin{array}{l}\text { No. 30: Convergence in Output in Transition } \\
\text { Economies: Central and Eastern Europe, } \\
\text { 1970-1995 }\end{array}$ & Saul Estrin and Giovanni Urga & February 1997 \\
\hline $\begin{array}{l}\text { No. 29: Published in: Economics of } \\
\text { Transition, "Altered Band and Exchange } \\
\text { Volatility." Volume 6, no. 1, 1998, 173-181. }\end{array}$ & Evzen Kocenda & March 1997 \\
\hline $\begin{array}{l}\text { No. 28: Published in: Quarterly Journal of } \\
\text { Economics, "Public Versus Private } \\
\text { Ownership of Firms: Evidence from Rural } \\
\text { China." Volume 113, no. 3, August 1998, 773- } \\
\text { 808. }\end{array}$ & Hehui Jin and Yingyi Qian & January 1997 \\
\hline $\begin{array}{l}\text { No. 27: East-West Joint Ventures in a } \\
\text { Transitional Economy: The Case of Slovakia }\end{array}$ & Sonia Ferencikova & March 1997 \\
\hline $\begin{array}{l}\text { No. 26: Published in Economic Analysis } \\
\text { "Behavior of a Slovenian Firm in Transition" } \\
\text { Vol. 1, no. 1, 1998, 57-73. }\end{array}$ & Janez Prasnikar & February 1997 \\
\hline $\begin{array}{l}\text { No. 25: Cultural Encounters and Claims to } \\
\text { Expertise in Postcommunist Capitalism }\end{array}$ & Michael D. Kennedy & February 1997 \\
\hline $\begin{array}{l}\text { No. 24: ZVU a.s.: Investment Funds on the } \\
\text { Board of Directors of an Engineering Giant }\end{array}$ & Tory Wolff & August 1995 \\
\hline $\begin{array}{l}\text { No. 23: The Role of Investment Funds in the } \\
\text { Czech Republic (joint publication with Czech } \\
\text { Management Center) }\end{array}$ & Dusan Triska & June 1996 \\
\hline $\begin{array}{l}\text { No. 22: Czech Investment Fund Industry: } \\
\text { Development and Behaviour (joint publication } \\
\text { with Czech Management Center) }\end{array}$ & Richard Podpiera & May 1996 \\
\hline $\begin{array}{l}\text { No. 21: Restructuring of Czech Firms: An } \\
\text { Example of Gama, a.s. (joint publication with } \\
\text { Czech Management Center) }\end{array}$ & Antonin Bulin & June 1996 \\
\hline $\begin{array}{l}\text { No. 20: YSE Funds: A Story of Czech } \\
\text { Investment Funds (joint publication with } \\
\text { Czech Management Center) }\end{array}$ & Michal Otradovec & November 1995 \\
\hline $\begin{array}{l}\text { No. 19: První Investicni a.s., The First } \\
\text { Investment Corporation (joint publication } \\
\text { with Czech Management Center) }\end{array}$ & Jaroslav Jirasek & August 1995 \\
\hline $\begin{array}{l}\text { No. 18: PPF a.s., The First Private Investment } \\
\text { Fund (joint publication with Czech } \\
\text { Management Center) }\end{array}$ & Michal Otradovec & November 1995 \\
\hline $\begin{array}{l}\text { No. } 17 \text { Published in: Post-Soviet Geography } \\
\text { and Economics, "Russia's Managers in } \\
\text { Transition: Pilferers or Paladins?" Vol. } 37, \\
\text { o.7 (September 1996), pp. } 397-426 .\end{array}$ & Susan J. Linz and Gary Krueger & November 1996 \\
\hline $\begin{array}{l}\text { No. 16: Banks in Transition-Investment } \\
\text { Opportunities in Central Europe and Russia }\end{array}$ & $\begin{array}{l}\text { With commentary and edited by Anna } \\
\text { Meyendorff }\end{array}$ & January 1997 \\
\hline
\end{tabular}




\begin{tabular}{|c|c|c|}
\hline $\begin{array}{l}\text { Edited Transcript from } 31 \text { May } 1996 \\
\text { Conference in New York City }\end{array}$ & & \\
\hline $\begin{array}{l}\text { No. 15: Marketing in Transitional Economies: } \\
\text { Edited Transcript \& Papers from } 1 \text { April } 1996 \\
\text { Conference in Ann Arbor, Michigan }\end{array}$ & Compiled by The Davidson Institute & December 1996 \\
\hline $\begin{array}{l}\text { No. 14: Pensions in the Former Soviet Bloc: } \\
\text { Problems and Solutions. Published by } \\
\text { Council on Foreign Relations. "The Coming } \\
\text { Global Pension Crisis" New York, } 1997\end{array}$ & Jan Svejnar & November 1996 \\
\hline $\begin{array}{l}\text { No. 13: Enterprise Restructuring and } \\
\text { Performance in the Transition. Forthcoming } \\
\text { in Financial Systems in Transition: The } \\
\text { Design of Financial Systems in Central } \\
\text { Europe eds. Anna Meyendorff and Anjan } \\
\text { Thakor. }\end{array}$ & $\begin{array}{l}\text { Lubomir Lizal, Miroslav Singer, and Jan } \\
\text { Svejnar }\end{array}$ & December 1996 \\
\hline $\begin{array}{l}\text { No. } 12 \text { Published in: Journal of International } \\
\text { Marketing, "Executive Insights: Marketing } \\
\text { Issues and Challenges in Transitional } \\
\text { Economies." Vol. 5, No. 4, 1997, pp. 95-114. } \\
\text { Also published in: Marketing Issues in } \\
\text { Transitional Economies ed. Rajeev Batra. }\end{array}$ & Rajeev Batra & April 1997 \\
\hline $\begin{array}{l}\text { No. 11: Worker Trust and System } \\
\text { Vulnerability in the Transition from Socialism } \\
\text { to Capitalism }\end{array}$ & Andrew Schotter & August 1996 \\
\hline $\begin{array}{l}\text { No. } 10 \text { Published in: Comparative Economic } \\
\text { Studies, "Russian Firms in Transition: } \\
\text { Champions, Challengers, and Chaff." Vol. } \\
\text { 39, No.2, Summer 1997, pp. 1-36. }\end{array}$ & Susan J. Linz & July 1996 \\
\hline $\begin{array}{l}\text { No. 9: Corporate Debt Crisis and Bankruptcy } \\
\text { Law During the Transition: The Case of China }\end{array}$ & David D. Li and Shan Li & December 1995 \\
\hline $\begin{array}{l}\text { No. } 8 \text { Published in: Journal of Comparative } \\
\text { Economics, “A Theory of Ambiguous } \\
\text { Property Rights in Transition Economies: The } \\
\text { Case of the Chinese Non-State Sector.” Vol. } \\
\text { 23, No. 1, August 1996, pp. 1-19. }\end{array}$ & David D. Li & June 1996 \\
\hline $\begin{array}{l}\text { No. 7: The Foreign Economic Contract Law of } \\
\text { China: Cases and Analysis }\end{array}$ & Dong-lai $\mathrm{Li}$ & June 1993 \\
\hline $\begin{array}{l}\text { No. 3: Bank Privatization in Hungary and the } \\
\text { Magyar Kulkereskedelmi Bank Transaction }\end{array}$ & Roger Kormendi and Karen Schnatterly & May 1996 \\
\hline $\begin{array}{l}\text { Replacing Nos. 1-2 \& 4-6: Journal of } \\
\text { Comparative Economics Symposium on } \\
\text { "Bank Privatization in Central Europe and } \\
\text { Russia." Vol. 25, No. 1, August } 1997 .\end{array}$ & $\begin{array}{l}\text { No. } 1 \text { "Bank Privatization in Transitional } \\
\text { Economies" by Roger Kormendi and } \\
\text { Edward Snyder. No. } 2 \text { "Transactional } \\
\text { Structures of Bank Privatizations in } \\
\text { Central Europe and Russia" by Anna } \\
\text { Meyendorff and Edward A. Snyder. No. } 4 \\
\text { "Bank Privatization in Poland: The Case } \\
\text { of Bank Slaski" by Jeffery Abarbaness and } \\
\text { John Bonin. No. } 5 \text { "Bank Privatization in } \\
\text { Post-Communist Russia: The Case of } \\
\text { Zhilsotsbank" by Jeffery Abarbanell and } \\
\text { Anna Meyendorff and No. } 6 \text { "'The Czech } \\
\text { Republic's Commercial Bank: Komercni } \\
\text { Banka" by Edward A. Snyder and Roger }\end{array}$ & August 1997 \\
\hline
\end{tabular}


